

PM-1 31\%2" $x$ 4" PHOTOGRAPHIC MICROCOPY TARGET NBS 1010a ANSI/ISO \#2 EOUIVALENT

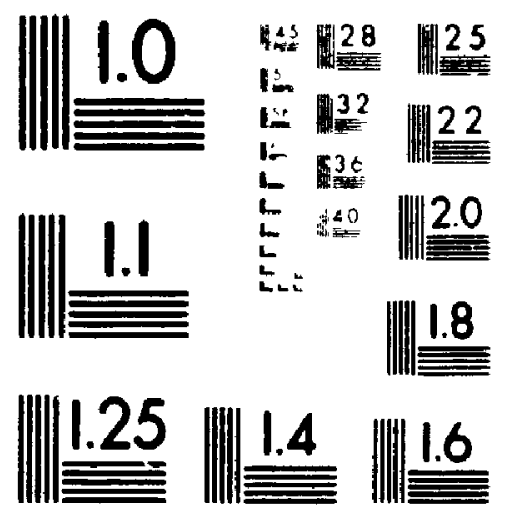

PRECISIONSM RESOLUTION TARGETS 


\title{
Metabolic adjustment and biochemical adaptation to torpor in mammalian hibernators
}

\author{
by
}

Marc Andrew de la Roche, B.Sc. (Hons)

\begin{abstract}
A thesis submitted
to the Faculty of Graduate Studies and Research

in partial fulfillment of

the requirements for the degree of

Master of Science

Ottawa-Carleton Chemistry Institute

Carleton Uriversity

Ottawa, Ontario

July, 1995
\end{abstract}

Ccopyright

1995, Marc Andrew de la Roche 
Direction des acquisitions et

des services biblographiques

395, rue Weltington

Otawa (Ontario)

K1A ON4
The atuthor has granted an irrevocable non-exclusive licence allowing the National Library of Canada to reproduce, loan, distribute or sell copies of his/her thesis by any means and in any form or format, making this thesis available to interested persons.
L'auteur a accordé une licence irrévocable et non exclusive permettant à la Bibliothèque nationale du Canada de reproduire, prêter, distribuer ou vendre des copies de sa thèse de quelque manière et sous quelque forme que ce soit pour mettre des exemplaires de cette thèse à la disposition des personnes intéressées.
The author retains ownership of the copyright in his/her thesis. Neither the thesis nor substantial extracts from it may be printed or otherwise reproduced without his/her permission.
L'auteur conserve la propriété du droit d'auteur qui protège sa thèse. Ni la thèse ni des extraits substantiels de celle-ci ne doivent être imprimés ou autrement reproduits sans son autorisation.

ISBN $\quad 0-612-13867-4$ 
Diecertation Abstracts Intemational is arranged by brood, general subject categories. Pleose select the one subject which most neorty describes the content of your dissertotion. Enter the corresponding four-digit code in the spoces provided.

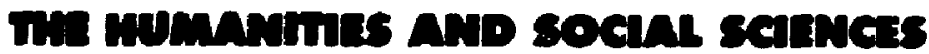

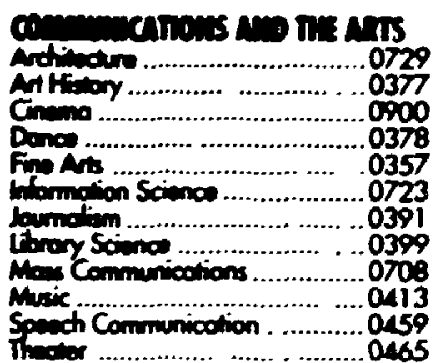

\section{:}

Geverd ..................................

Adninimition ......................0514

Adut and Continuing . ...........0516

Arriaghrod ..........................0517

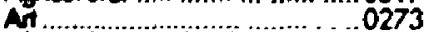

Qdingued and Muticulinurat .. ... 0282

Business ..........................0688

Communty College ................ . .

Curriat m and instruction ......0727

Eorty Childhood .............. . 0518

Elementory . . ................. 0524

Fimoper. $\ldots$ and Counseling .....0519

Guidance and Counseling.. .050 .0680$

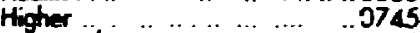

History of ... .............. ..0520

Heme Econornics ............. .0278

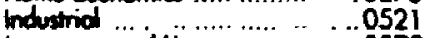

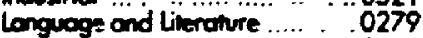

Matinemotos .. ............. 0280

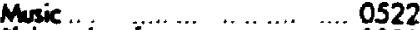

Phloxcophy of $\ldots . . . . .6 . . .0998$

Phrsical. .............. . . 0523

\section{THE SCIBNCES AND ENGINEERING}

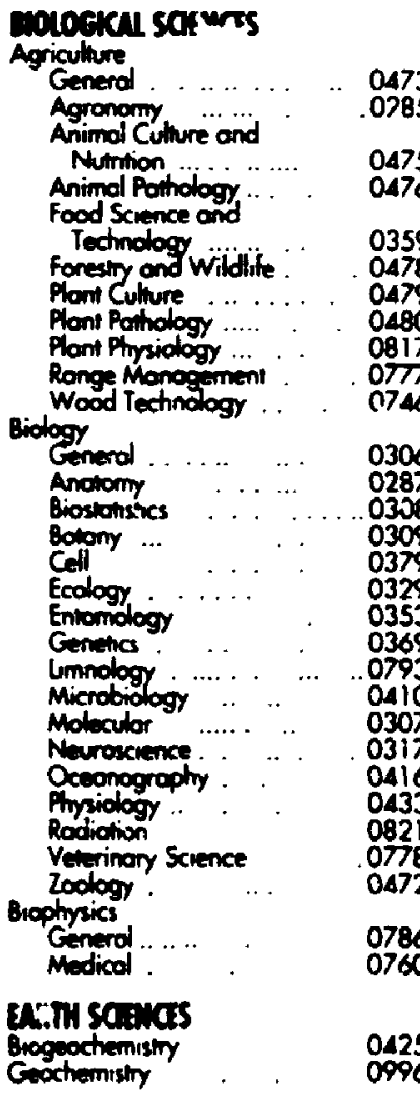



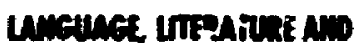
Hireustics

longuoge

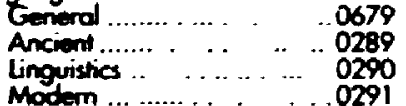

Literoture

Clossica! ...... 029

$\begin{array}{lll}\text { Comporative ... ...... } & 0295 \\ \text { Madiond } & 0297\end{array}$

Modev .....$\quad .0298$

African .... ... 0310

Americon. .. ... . 059

. 0305

Conodion (English) $\quad 0352$

Conodian (french) . . $\quad 0355$

Gemonic … 0311

Lotin Americon ... . 0312

Middle Eastern . . 0315

Romance

0313

Slavic and Eorst Eurapean 0314
Gererd. ... ... 0401

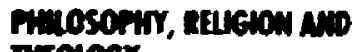

\section{Theolosy}

Philosophy

Religion

Enero.

Clergy

History of

Theology

\section{sogn sagics}

Amencon Sindies

Anthropology

Anchoedog

Cultural

Business Adrunistrotion

Generd..

Accounting

Bonking

Monogement

Conodion Stidies

Economics

Generol

Agricultural

Finance

History

Lobor

Follkbre

Geogrophy

Geróniolog)

History

Generol

$\begin{array}{ll}\text { Geociesy } & 0370 \\ \text { Geotogy. ... } & 0372 \\ \text { Geophysics . . } & 0373 \\ \text { Hydrology .. . } & 0388 \\ \text { Minerology . } & 0411 \\ \text { Poleobolory } & 0345 \\ \text { Poleoecology } & 0426 \\ \text { Poleontology } & 0410 \\ \text { Poleozoology } & 0985 \\ \text { Potynology. } & 0427 \\ \text { Phrsical Eeogrophy } & 0368 . \\ \text { Physical Oceorogrophy } & 0415\end{array}$

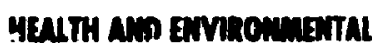

\section{solexas}

Environmentol sciences

0768

Heodih Sciences

Generol

Audiology

Chemotherapy

Dentisiny

Edurotion

Mospitol Monogement

Humon Devilopment

Immunology

Medicine ond Surgery

Mentol Healit

Nursing

Obstetrics and Srnecology 0320

Occupotional Heolith ond

Theropy

Ophinolmology

Pothology.

Phormocology

Phormocy

Physicol therapy

futclic Hoolith

Rodiology

Recreotion
057

0572

0382

057

0575
Speech Pothology

Toxicology

\section{PHTSKal satiras}

Pure Sciences

Chemisiny

General

Agriculturol

Anolytical

Biochernistr

Inorgon'c

Nucleor

Orgonic

Phómocentical

Physical

Polymer

Rodiotion

Mothemotics

Physics

Generol

Acoustics

Astronormy and

Astrophysies

Amosoheric Scrence

Alomie

Elentrones and Eloctricing

Elementory Poncles and

High Eriergy

Fluid and Ploims

Moleculor

Nucleor

Optics

Rodiction

Solid Stote

Stothetics

Applind Sciences

Applied Mechonics

Compuner Science
Home Econornics
Ancient

Modievol

Modern

Block

Asso. Austrake and Oteono 0332

Europon

Loin Americon

Mudate Eostorn

Unvied Siotes

History of Serence

Lon

Political Science

Generd

Internotionol low and

Relations

Public Administrotion

Recrection

Sociol Work

Sacrology

Crminolagy and Penalogy 0627

Demogrophy 0938

Ethnic and Rociol Studies 0631

Indinduol and fomily.

Shudies

Industrial and Labor

Relations

0628

Saciol Structure and

Development

Theory and Methods

Tronsportotion

Women's Studies

0629

0630

0700

0709

0999

0453

0336

0337

0615

(2)

114

52
Conodion 033

General 0626

Public and Sociol Wethore
0351

0578
0450

0383

0386

Eng

Gernera

Aerospoce

Agriculural

Biomedical

Chemical

Civil

Eiectronics and Eloctrical

Heot and Thermodynomics

Hydroulic

Industringl

Morine

Motericts Science

Mochonicol

Mewallurgy

Muning

Pockoging

Petroleum

Sonitory and Municipol

Sywem Science

Geovechnology

Operotions Reseorch

Plastiss iechnotegy

Textile Technology

Pranceor

Grineral

Bethovioral

Clinicol

Dexulopmentol

Experimental

Industrinal

Persondily

Prysiological

Pischobiclogy

Pinchometris:

0346

Social
0537

0538

0539

7543

4544

0348

0545

0546

0547
0794

0548

0743

0551

OS52

0549

0765

0554
0700

0428

4796

0795

0994

0621

0384 
The undersigned hereby recommend to the Faculty of Graduate Studies and Research acceptance of the thesis

\title{
"Metabolic adjustment and biochemical adaptation to torpor in mammalian hibernators"
}

\author{
submitted by \\ Marc Andrew de la Roche, B.Sc. (Hons) \\ in partial fulfillment of the requirements for \\ the degree of Master of Science
}


Carleton University

1995 


\begin{abstract}
Hibernating mammals have evolved the ability to lower their metak.olic rate in response to temperate conditions and/or lack of food and water. At the level of enzyme control, this is accomplished by the coordinated suppression of all metabolic processes and the rearrangement of metabolic flux to maximize fuel stores. The quantification of 32 enzyme activities in 5 tissues of hibernating versus euthermic golden-mantled ground squirrels (Spermophilus lateralis) demonstrated a decreased potential in glycolysis, biosynthetic processes and carbon entry from glycolysis into the TCA cycle relative to an increased potential in fatty acid oxidation during hibernation. This was further supported by studies on ketone body metabolism, a product of fatty acid oxidation. Kinetic characterization of $ß$-hydroxybutyrate dehydrogenase $(B D H)$ and glycerol-3phosphate dehydrogenase (G3PDH) established unique functional adaptations of these enzymes in S. lateralis and Cynomys ludicivicianus. Using temperature and chemical denaturants as probes, purified G3PDH from a hibernator was fo' Ind to have a greater chemical and thermal stability, and maintained both structural and functional integrity at lower temperatures relative to the enzyme from rabbits. These results purport a unique metabolic state during hibernation and demonstrate both structural and functional adaptations of hibernator enzymes to cold stress.
\end{abstract}




\section{Acknowledgements}

My gratitude goes to Kenneth Storey who was an invaluable source of inspiration and knowledge t'רroughout my two years at Carleton. Thanks also go to Janet Storey for her patient teaching of 'the basics' and proofreading this manuscript. Appreciation goes out to all of my labmates for putting up with me over the past two years. Finally, I would like to acknowledge my parents, Nicole and lan for their support, and Peter, Sheila and Gavin Carr for their friendship. 


\section{Table of Contents}

Page

Title page

Acceptance sheet

ii

Abstract

iiî̀

Acknowledgements

iv

Table of contents

v

List of abbreviations

vi

List of Tables

ix

List of Figures

$x$

Chapter 1. General Introduction

Chapter 2. Enzyme survey of Spermophilus lateralis tissues

Chapter 3 . The nature of ketone body metabolism in Spermophilus lateralis

Chapter 4. Purification and characterization of muscle glycerol-3-phosphate

$60-83$ dehydrogenase from Cynomys ludivicianus, and rabbits.

Chapter 5. General discussion

Appendices

$89-92$

References

$93-99$ 


\section{List of Abbreviations}

$A A$ - acetoacetate

ALAAT - alanine aminotransferase

ALD - aldolase

ASPAT - aspartate aminotransferase

ATP, ADP , AMP - Adenosine tri-, di- and mono-phosphate

ATPCL - ATP-citrate lyase

$\mathrm{KADH}$ - branched chain ketoacid dehydrogenase

COT - carnitine-octanoyl tranferase

CPT - carnitine-palmitoyl transferase

CS - citrate synthase

DE-52 - diethylamino cellulose

DHAP - dihydroxyacetone phosphate

EDTA - ethylenediamine tetraacetate

EGTA - ethyleneglycol bis( $\beta$-aminoethyl ether) tetraacetate

F2,6 $P_{2}$ - Fructose-2,6-bisphosphate

FAS - fatty acid synthetase

FBPase - fructose-1,6-bisphosphatase

GK - glucokinase

G6PDH - glucose-6-phosphate dehydrogenase

GDH - glutamate dehydrogenase

G3PDH - glycerol-3-phosphate dehydrogenase

G3P - glycerol-3-phosphate

HK - hexokinase

HOAD - 3-hydroxyacyl-CoA dehydrogenase 
BDH - B-hydroxybutyrate dehydrogenase

BOHB - B-hydroxybutyrate

$\mathrm{NADIDH}$ - (NAD+ dependent) isocitrate dehydrogenase

NADPIDH - (NADP + dependent) isocitrate dehydrogenase

$\mathrm{KGDH}$ - $\alpha$-ketoglutarate dehydrogenase

$\mathrm{Km}$ - Concentration of suhstrate at which the enzyme reaction proceeds at $50 \%$ of its maximal velocity

LDH - lactate dehydrogenase

$\mathrm{NAD}^{+}, \mathrm{NADH}$ - oxidized and reduced forms of nicotinamide adenine dinucleotide

$\mathrm{NADP}^{+}, \mathrm{NADPH}$ - oxidized and reduced forms of nicotinamide dinucleotide phosphate

NADMDH - (NAD+ dependent) malate dehydrogenase

NADPMDH - (NADP+ dependent) malate dehydrogenase

NaF - Sodium fluoride

ME - malic enzyme

PDH - pyruvate dehydrogenase

PEPCK - phospioenolpyruvate carboxykinase

PFK - 6-phospho-1-fructokinase

6PGDH - 6-phosphogluconate dehydrogenase

PK - pyruvate kinase

pKa - proton dissociation constant

PMSF - phenylmethylsulfonyl fluoride

Q10 - the factor by which a $10^{\circ} \mathrm{C}$ temperature change reduces the rate of a chemical reartion

SDH - serine dehydratase 
TCA Cycle - Tricarboxylic acid cycle

U/gww - International units per gram wet weight

$V_{\text {max - maximal enzyme velocity }}$

WAT - white adipose tissue 


\section{List of Tables}

Page

1.1 Various forms of metabolic arrest in nature and the responsible environmental ir.fluence.

2.1 Soluble proiein concentrations of Spermophilus lateralis tissues

2.2 Maximal activities of enzymes that were unchanged in $S$. lateralis tissues during hibernation.

2.3 Trends observed in metabolic pathways during hibernation relative to euthermia.

3.1 Concentrations of B-hydroxybutryate in tissue extracts from of rat, Cynomys ludivicianus and S. lateralis.

3.2 Maximal activities of B-hydroxybutyrate dehydrogenase in liver extracts from rat, $S$. lateralis and $C$. Iudivicianus.

3.3 Substrate affinity constants for $\mathrm{NAD}^{+}, \mathrm{NADH}$ and acetoacetate at $5^{\circ} \mathrm{C}$ and $22^{\circ} \mathrm{C}$.

3.4 Activation energies for liver B-hydroxybutyrate dehydrogenase in liver extracts of rat, Cynomys ludivicianus and S. lateralis.

4.1 Typical purification protocol for glycerol-3-phosphate dehydrogenase

4.2 Maximal activities of glycerol-3-phosphate dehydrogenase in crude extracts of muscie and liver from rabbit and $C$. ludivicianus.

4.3 G3PDH substrate affinity constants for $\mathrm{NAD}^{+}, \mathrm{NADH}$ and dihydroxyacetone phosphate at 22 and $5^{\circ} \mathrm{C}$. 


\section{List of Figures}

2.1 Maximal enzyme activities in liver extracts

2.2 Maximal enzyme activities in kidney extracts

2.3 Maximal enzyme activities in heart extracts

$2.4 \quad$ Maximal enzyme activities in muscle extracts

2.5 Maximal enzyme activities in white adipose tissue extracts

$2.6 \quad$ Total activity of pyruvate dehydrogenase and the percentage of the enzyme in the active a form in kidney and heart of $S$. lateralis

3.1 The effect of temperature on binding affinities of

B-hydroxybutyrate dehydrogenase in liver extracts from rat, $S$. lateralis and $C$. Iudivicianus.

4.1 SDS-PAGE of purified glycerol-3-phosphate dehydrogenase from $C$. ludivicianus liver and muscle.

4.2 The effect of temperature on binding affinities of purified muscle glycerol-3-phosphate dehydrogenase from $C$. ludivicianus and rabbit.

4.3 The effect of temperature on the fluorescence emission intensity (at $\lambda_{\max }=340 \mathrm{~nm}$; excitation $=280 \mathrm{~nm}$ ) of purified muscle glycerol-3-phosphate dehydrogenase from C. ludivicianus and rabbit.

4.4 The effect of incubation at $37^{\circ} \mathrm{C}$ on the activity of purified muscle glycerol-3-phosphate dehydrogenase from $C$. ludivicianus and rabbit over 60 minutes.

4.5 The effect of increasing guanidine hydrochloride concentration on the fluorescence emission spectrum of purified muscle glycerol-3-phosphate dehydrogenase from $C$. Iudivicianus and rabbit; Inset - the corresponding effect of guanidine hydrochloride on activity. 
Chapter 1

General introduction 
To avoid the metabolic cost of maintaining a constant high body temperature throughout the winter, some mammals have developed the ability to hibernate. This is an energy sparing strategy characterized by a reduction in body temperature concurrent with the reduction in ambient temperature. As well, - metabolic processer :vithin these animals are substantially reduced in order to minimize the consumption of metabolic fuel and production of metabolic waste. In nature, diverse species employ similar strategies in response to various environmental insults. A short list is presented in Table 1.1. Each of these strategies is a unique adaptation, however, they are all characterized by a profound reduction in metabolic rate.

Hibernation represents a major thermoregulatory adaptation in some mammalian species in response to cold conditions and lack of food. Whereas homeothermic species must utilize the majority of their metabolic fuel to maintain a consiant body temperature (Wang 1989), hibernating species have abandoned this necessity. The eifectiveness of such a strategy has been demonstrated in Richardson's ground squirrels (Spermophilus richardsonii) where Wang (1979) has calculated an $88 \%$ energy savings for the hibernator rel ative to the cost of remaining awake throughout the winter season.

The course of hibernation consists of a series of torpor bouts which can be divided into four metabolic states; preparation/storage, entry, hibernation and arousal. The signal for priming metabolism into a storage mode prior to hibernation is unknown, as is the signal for the entrance into hibernation. Many attempts have been made to prove the existence of a neuropeptide called the Hibernation Induction Trigger (HIT molecule; Galster 1978; Nedergaard and Canon 1990), however the present author believes a more plausible signal is a 
combination of photoperiod, ambient temperature, diet composition (food composit.on changes over the course of summer) and food availability. These factors would be expected to effect hormone levels which in turn implicates genetic regulation of this processe; however there is a disparity of literature concerning genetic control over the entrance into hibernation.

The extreme metabolic changes that occur throughout a bout of torpor belie deliberate and controlled changes in metabolic flux to ensure optimal use of stored fuel resources. Four to six weeks prior to the entrance into hibernation, metabolic fuel, in the form of triglycerides, is stored in lipid depots throughout the body of the animal. This is readily seen during the fall when ground squirrels effectively double their body size and maximizing their triglyceride stores. This is the most efficiently stored source of metabolic fuel for mammals and can satisfy the energy requirements of the animal throughout a winter season (Nedergaard and Canon 1984).

The entrance into hibernation can occur over the course of a few hours to several weeks depending on the species and depth of hibernation (Wang 1978). Body temperature falls with ambient temperature until the hypothalamic set-point is reached. In S. richardsoni, this corresponds to a body temperature of $2-3^{\circ} \mathrm{C}$, below which point the animal will actively thermoregulate regardless of ambient temperature (Wang 1978). During torpor, metabolic rate is substantially reduced, demonstrated by the reduction of oxygen consumption to less than $1 \%$ of euthermic, resting levels. The energy needs of the animal are almost entirely met by lipids, with some small contribution by carbohydrate stores. 
Relative to the entrance into torpor, arousal is an explosive event that takes from 20 minutes to a few hours depending on the size of the animal. Nonshivering thermogenesis in brown adipose tissue provides initial rewarming, followed by eventual carbohydrate mobilization used to fuel shivering in peripheral muscle tissues (Wang 1987). Arousals occur periodically throughout the hibernating season (for ground squirrels every 2.3 weeks (Wang 1978)) and are very costly to the animal. Wang (1978) has estimated that these arousals represent as much as $90 \%$ of overall fuel consumption durinig the hibernation season. The reason for these periodic arousals is unknown, however many hypotheses have been put forward. These include the restoration of ionic balance, the replenishn,ent of carbohydrate reserves, the elimination of metabolic waste, or simply 'catching up' on REM sleep.

The duration of torpor bouts varies widely among species and may last from a single night in daily heterotherms such as the deer mouse (Peromyscus maniculatus; Nestler 1992), to as long as 90 days in the big brown bat (Eptesicus fucus; Yacoe 1983). The depth of hibernation is the degree to which metabolic rate is depressed and car be represented by the body temperature during torpor relative to euthermia. Both duration and depth of torpor bouts are indices of relative hibernation 'ability' among species which can be applied to the two hibernators in this study.

Golden-mantled ground squirrels (Spermophilus lateralis) are profound hibernators with an obligatory hibernation season. They are approximately $30 \mathrm{~cm}$ in !e. Th (Michener and Koeppl 1985) and can reduce their body temperature to as low as $5^{\circ} \mathrm{C}$ for up to 14 days when kept at $3-5^{\circ} \mathrm{C}$ in the absence of food (Twente and Twente 1965). This species is commonly found in the mountains of 
northern California and its hibernation physiology has been extensively studied (Snapp and Heller 1981). Black-tailed prairie dogs (Cynomys ludivicianus) are a larger species (approximately $35 \mathrm{~cm}$ in length) and inhabit the Colorado lowlands where they experience much milder climatic conditions (Tileston and Lechleitner 1966). This is reflected in the depth and duration of their hibernation bouts; they hibernate irregularily during winter months for up to 24 hours with a body temperature as low as $13^{\circ} \mathrm{C}$ (Fevold 1986; Harlow and Menkens 1985).

The size of a hibernator is a prominent factor in determining the respective hibernating 'ability' of the animal. This is a parameter that has received much attention in the literature (Nedergaard and Canon 1990). Indeed, the big brown bat Eptescius fucus is the most profound of hiternators and one of the smallest (Yacoe 1983). In contrast, the largest of all hibernating mammals is the brown bear which has vely limited hibernation ability (it can only depress its metabolism to $40 \%$ of euthermic levels) despite its romantic role as the 'classical hibernator' (Nedergaard and Canon 1984). The reason for this is that the amount of fuel reserves that can be stored is inversely proportional to size, making hibernation less likely in larger animals.

Metabolic control over the depression of metabolism during torpor is poorly understood. Some attention has focused on a passive reduction in metabolism brought about by the reduction in body temperature. This is explained by the $Q_{10}$ effect which is used to describe the change in rate of a chemical reaction in response to temperature. $A Q_{10}$ of 2 is characteristic of chemical reactions and denotes a 2-fold decrease in the rate of a reaction for every $10^{\circ} \mathrm{C}$ decrease in temperature. For enzyme catalyzed reactions, $Q_{10}$ values range from 2-3, and would predict an 8-27-fold reduction in metabolic rate 
for a reduction in body temperature from 37 to $5^{\circ} \mathrm{C}$. However, most hibernators experience a markedly greater reduction of metabolic rate than predicted from temperature effects (Wang 1987). One way this may occur is by an increased suppression of metabolic processes induced by hypercapnia, a result of apnoic (non-rythmic, lowered) breathing during torpor. This effect may be further exaggerated by the relative change in the pKa of intra- and extracellular buffering agents with reduced body temperature. Another explanation advocates an active suppression and maintenance of metabolic rate. In support of this, the slow and deliberate entrance into hibernation relative to arousal purports a highly regulated process. Furthermore, metabolic arrest occurs prior to the reduction in body temperature which indicates an active rather than passive suppression of metabolic processes. This prompts the question; are there unique functional adaptations at the level of enzyme control that are characteristic of hibernating species? These adaptations would be responsible for both the reduction of overall metabolic rate, and the induction of functional changes in metabolic flux during torpor. With respect to the latter, this includes the increased use of triglycerides as a source of fuel relative to a decrease in the use of more limited fuel reserves such as protein and carbohydrate. This metabolic state may be accomplished by a variety of mechanisms which include : structure-function changes in enzymes relative to reduced temperature (Chapters 3 and 4 present study); changes in the concentrations of regulatory enzymes (Chapter 2 present study); post translational modification of key regulatory enzymes (Storey 1987a); reversible aggregation of enzymes (Srivastava and Bernhard 1986; Srere and Ovadi 1990) or their binding to subcellular structures (Arnold and Pette 1970); and changes in concentrations of enzyme inhibitors and activators. The present study will consider the contribution of the first two mechanisms in determining the overall metabolic state of hibernating species during bouts of torpor. 


\section{Methodology}

A comparison of maximal enzyme activities between a euthermic and a hibernating animal is key for the determination of metabolic flux during torpor. This also allows for an evaluation of the contribution of this mode of enzyme control. In vitro determination of enzyme activities has long been employed for the determination of regulatory sites in metabolic pathways; whereas nonregulatory enzymes exhibit relatively high activity activities, regulatory enzymes must be rate limiting and typically of low activities (Newsholme and Crabtree 1986). Furthermore, changes in the potential for met:abolic flux during hibernation can be estimated by comparison to maximal activities of enzymes during euthermia.

Unique functional adaptations in hibernating species can be explored in terms of structure - function relationships of enzymes. Siructure and function are two intimately related characteristics of enzymes whereby the subtlest of enzyme deformity can have a large effect on its catalytic ability. During hibernation, both temperature and $\mathrm{pH}$ can play a role in altering the physical 'appearance' of an enzyme and will thus modulate activity. The extent of temperature effects can be evaluated by comparing structural and functional parameters between enzymes from hibernating and non-hibernating mammalian species. The present study will address the following parameters:

i) Energies of activation (determined from Arrhenius plots), which serve as indicators of the temperature effect on thermodynamic properties of the enzyme (i.e. activation energy and $Q_{10}$ value), will be measured. Past studies suggest that enzymes of non-hibernating species may exhibit conformational transitions 
with lowered temperature that are responsible for suppression of enzyme activity. This is shown by a break in the Arrhenius plot (Borgmann and Moon 1976). Hibernating species, on the other hand, require function over a range of temperatures and must maintain normal enzyme function.

ii) Assessment of $\mathrm{pH}$ effects on enzymes at different temperatures will be used to determine the effects of acidotic inhibition on enzymes during hibernation. With the use of imidazole buffer, one whose pKa mimics that of intracellular buffering agents, $\mathrm{pH}$ optima 'shifts' with temperature can be monitored to determine if this is a control mecharism for reducing activity via hypercapnia induced acidosis.

iii) Structural parameters of an enzyme can be determined from changes in the intrinsic fluorescence of tryptophan residues. Because both emission wavelength and fluorescence intensity are a function of the microenvironment, the effect of temperature and other structural modifiers can be monitored by their effect on enzyme fluorescence. This will be used to evaluate structural parameters of purified glycerol-3-phosphate dehydrogenase (G3PDH) from C. ludivicianus muscle relative to the enzyme from rabbit muscle.

iv) Kinetic parameters of enzymes are a function of the structure of an enzyme and can also be used to evaluate enzyme perturbation at sperific sites (active site or allosteric site) induced by temperature. In the present study, $\mathrm{Km}$ values will be used as an indicator of functional changes in B-hydroxybutyrate dehydrogenase (BDH) and G3PDH with lowered temperature. 
The present study will elucidate specific metabolic and enzyme adaptations in hibernating species in an attempt to evaluate their contribution to the process of hibernation. This will be done with consideration of enzyme activities in various pathways as indicators of changes in metabolic flux potential. In addition, unique structural and functional features of hibernator enzymes will be explored. Model systems used in this study are black-tailed prairie dogs (Cynomys Iudivicianus), golden-mantled ground squirrels (Spermophilus lateralis) and two non-hibernating controls, laboratory rats and rabbits. 
Table 1.1. Various forms of metabolic arrest in nature and the responsible environmental influence. 


\begin{tabular}{|c|c|c|c|c|c|c|c|c|c|c|c|c|}
\hline  & 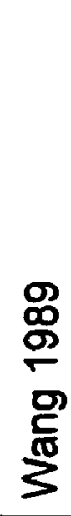 & & 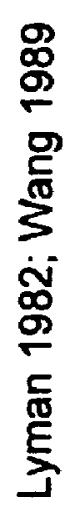 & &  & $\begin{array}{l}\dot{R} \\
\tilde{\sigma}\end{array}$ &  & & &  & $\begin{array}{l}\text { \% } \\
\text { \% } \\
\text { 市 } \\
\frac{0}{0}\end{array}$ & \\
\hline 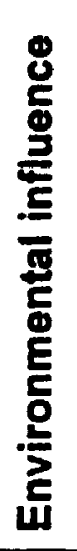 & 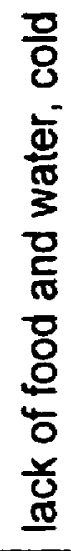 & 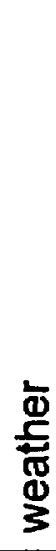 & 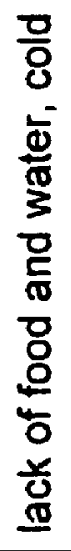 & 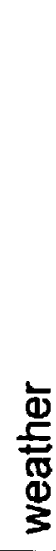 & 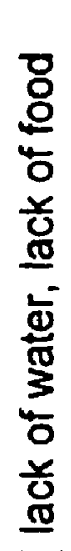 & & 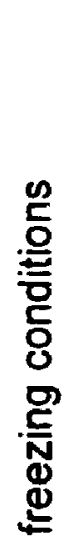 & & & 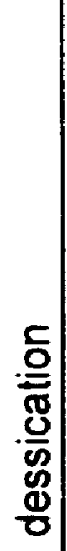 & 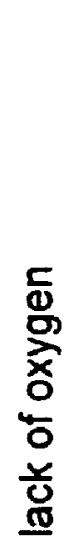 & \\
\hline  & 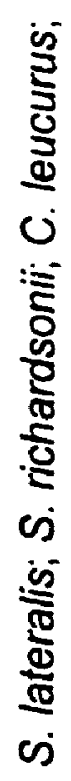 & 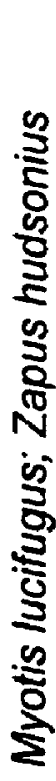 & 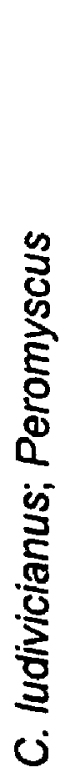 & 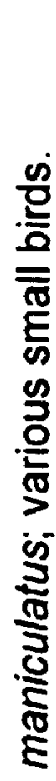 &  & $\begin{array}{l}\frac{5}{5} \\
\frac{5}{5} \\
\vdots\end{array}$ & 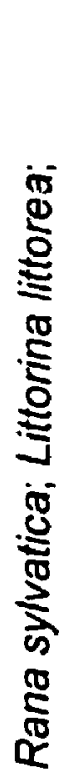 & 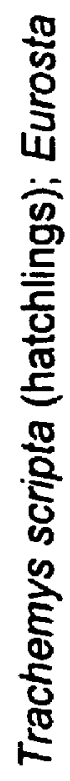 & 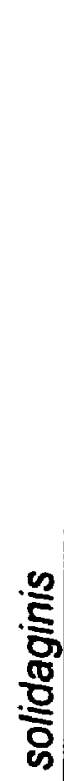 & 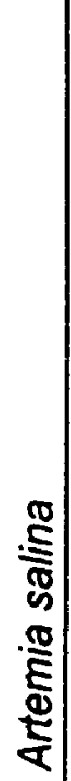 &  & 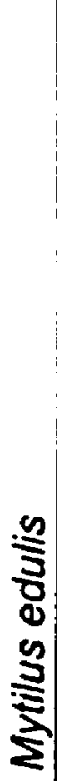 \\
\hline 总 & 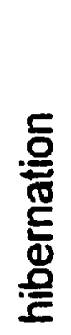 & & $\begin{array}{l}\frac{6}{0} \\
\frac{2}{0} \\
\frac{2}{0}\end{array}$ & & 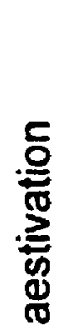 & & 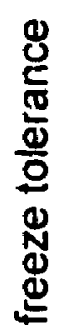 & & & $\begin{array}{l}\frac{n}{5} \\
\frac{0}{2} \\
\frac{0}{0} \\
\frac{0}{c} \\
\frac{c}{0}\end{array}$ & 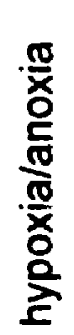 & \\
\hline
\end{tabular}




\section{Chapter 2}

Changes in metabolic flux potential during hibernation in the golden-mantled ground squirrel Spermophilis lateralis. 


\section{Introduction}

The golden-mantled ground squirrel, Spermophilus lateralis, is a hibernator that can lower its body temperature to between $2-15^{\circ} \mathrm{C}$ for up to two weeks (Snapp and Heller 1981). These periods of torpor are characterised by the reduction of overall metabolic rate accompanied by the lowering of body temperature. Metabolic adjustments involve a general reduction of protein and carbohydrate metabolism relative to mobilization of triglyceride reserves. At the level of enzyme control this may be accomplished in a number of ways : temperature effects on enzyme structure and function (see Chapters 2 and 3), post translational modification of key regulatory enzymes (Storey 1987); acidotic inhibition of enzymes (Malan 1993; Malan 1980); reversible aggregation of enzymes (Srivastava and Bernhard 1986; Srere and Ovadi 1990) or binding to subcellular structures (Arnold and Pette 1970); changes in concentrations of effectors; and changes in the concentrations of regulatory enzymes (present chapter). This study will consider the role of the latter in determining overall metabolic flux and sites of regulation during hibernation in S. lateralis.

In vitro determination of enzyme activities has long been employed to provide insight into their potential flux in vivo. Accordingly. maximal activities can be used to identify key regulatory sites in addition to assessing changes in potential carbon flux throughout metabolic pathways. Non-regulatory enzymes exhibit relatively high activity, whereas regulatory enzymes must be rate limiting and are usually of low activity (Newsholme and Crabtree 1986). Enzyme maximal activities, however, serve only as an indicator of the potential for maximal substrate flux through any given pathway, the actual 
flux at any given time being subject to the other modes of control previously mentioned. However, the utility of enzyme activity measurements is valid for two reasons; i) the subtlest of changes in enzyme concentration can induce catastrophic effects throughout the intricacies of metabolism; ii) changing enzyme concentrations via protein synthesis or degradation is an enormous burden on precious me abolic energy, a factor that suggests its importance, hence any changes found in the hypometabolic, hibernating state suggest their key importance.

The present study will determine the specific activities of 32 enzymes in 5 tissues of hibernating and euthermic $S$. laterali:. These will be used as indicators of metabolic flux in the pathways of glycolysis, fatty acid catabolism and synthesis, amino acid catabolism, the TCA cycle and gluconeogenesis. 


\section{Materials and Methods}

\section{Chemicals and animals}

All chemicals were purchased from Sigma Chemical Company (St.

Louis, Mo., U.S.A.), or from Boehringer Mannheim (Montreal, Quebec) and were of the highest purity available. Twenty-one Spermophilus lateralis were captured in the White Mountains of California during June 1992. All animals were individually housed in rat cages at the animal care facility of the University of California, !rvine and maintained at $22^{\circ} \mathrm{C}$ on a fall (10L:14D) photoperiod. At the end of an 8 week feeding pericd, half of the animals were induced to hibernate by placing their cages in a cold room at $4^{\circ} \mathrm{C}$ on the same photoperiod. After a $24 \mathrm{~h}$ habituation period, all food (but not water) was withheld. During the first nine days of fasting, the telemetered body temperature of each animal (telemeters were implanted during the initial 8 weeks) was measured every $12 \mathrm{~h}$ to determine the onset of hibernation. Those that did not enter torpor within this period were removed from the cold room. Those that did hibernate were maintained at $4^{\circ} \mathrm{C}$ for one month at which time all animals were sacrificed. Ratus ratus were obtained from the animal care facility at Carleton University. All animals were killed by decapitation and excised tissues were immediately immersed in liquid nitrogen and subsequently stored at $-70^{\circ} \mathrm{C}$. 


\section{Preparation of Homogenates}

Unless otherwise stated, all extracts were prepared by homogenizing tissues (1:6 w/v, approximately $60 \mathrm{mg}$ per preparation) in ice cold $20 \mathrm{mM}$ imidazole, pH 7.5, containing $10 \%$ v/v glycerol, $100 \mathrm{mM} \mathrm{NaF}, 30 \mathrm{mM}$ Bmercaptoethanol, 5 mM EDTA and 5 mM EGTA with a Diamed Pro 200 homogenizer set to full power followed by centrifugation in a Heraeus Biofuge 15 at $20000 \times \mathrm{g}$ for 25 minutes. The supernatant fraction was collected and stored on ice prior to assay. Extracts for carnitine-palmitoyl transferase, carnitine octanoyl transferase and citrate synthase were also prepared as above, except that the $\mathrm{pH}$ of the extraction buffer was set to 8.1 and $\mathrm{NaF}$ and B-mercaptoethanol were omitted. Extracts for pyruvate denydrogenase (PDH) assays were prepared as above in buffer containing $50 \mathrm{mM}$ potassium phosphate, pH 7.8 containing $2 \mathrm{mM}$ B-mercaptoethanol, $1 \mathrm{mM}$ EDTA and $0.1 \%(w / v)$ Triton $X-100$; the samples were subsequently frozen at $-20^{\circ} \mathrm{C}$ for one hour and thawed prior to assay of active PDH, a process that helps to break up mitochondrial membranes (S. Brooks, personal communication). Total PDH activity was determined in aliquots of crude homogenate incubated 1:1 (v/v) with $20 \mathrm{mM} \mathrm{MgCl}_{2}$ and $2 \mathrm{mM} \mathrm{CaCl}_{2}$ at timed intervals of 10 minutes up to 40 minutes with results then extrapolated to time $=0$ to yield initial activity.

Partially purified arylamine transferase (for PDH assays) was prepared by homogenizing chicken livers (1:3 w/v, approximately $300 \mathrm{~g}$ per preparation) in ice cold $50 \mathrm{mM}$ Tris, $\mathrm{pH} 8.0$ containing $2 \mathrm{mM}$ EDTA, $10 \mathrm{mM}$ Bmercaptoethanol and a few crystals of PMSF. The homogenate was centrifuged at $8000 \times g$ for 30 minutes at $5^{\circ} \mathrm{C}$. Polyethyleneglycol 8000 was 
then added slowly to the decanted supernatant with stirring to $20 \% \mathrm{w} / \mathrm{v}$ before a second centrifugation as above. The $\mathrm{pH}$ of the supernatant was adjusted to 8.0 and then it was applied to a DE-52 column equilibrated in 20 $\mathrm{mM}$ Tris bufter, $\mathrm{pH} 8.0$ containing $10 \mathrm{mM}$ B-mercaptoethanol. The partially purified enzyme was eluted with a gradient of 0 to $500 \mathrm{mM} \mathrm{KCl}$ in the same buffer. Active fractions were collected and stored in $40 \% \mathrm{v} / \mathrm{v}$ glycerol at $-20^{\circ} \mathrm{C}$ until use.

\section{Determination of enzyme activity}

Unless otherwise stated, all assays were performed at $22.5^{\circ} \mathrm{C}$ using a Dynatech MR5000 microplate reader in a final volume of $0.250 \mathrm{ml}$ plus added extract at an absorbance of $340 \mathrm{~nm}$. Optimal assay conditions were determined for each enzyme using rat liver extracts and these conditions were used for assays in all S. lateralis tissues. Controls for non-specific activity (measured in the absence of the most specific substrate) were subtracted to yield net activity values. One units (IU) of activity is defined as the amount of enzyme that produced one $\mu$ mole of product per minute at $22^{\circ} \mathrm{C}$. Before use, coupling enzymes were desalted by centrifugation through a small column of G-25 (Helmerhorst and Stokes 1980). Optimal assay conditions were as follows :

Glucokinase (GK; E.C. 2.7.1.2) : $100 \mathrm{mM}$ tris buffer (pH 8.0), $1 \mathrm{mM}$ EDTA, $2 \mathrm{mM} \mathrm{MgCl}_{2}, 100 \mathrm{mM}$ glucose, $0.2 \mathrm{mM} \mathrm{NADP}^{+}, 1 \mathrm{mM}$ ATP and $1 \mathrm{U}$ glucose-6-phosphate dehydrogenase. Hexokinase activity was subtracted to yield net glucokinase activity. 
Hexokinase (HK; E.C. 2.7.1.1) : $100 \mathrm{mM}$ tris buffer (pH 8.0), $1 \mathrm{mM}$ EDTA, $2 \mathrm{mM} \mathrm{MgCl} 2,10 \mathrm{mM}$ glucose, $0.2 \mathrm{mM} \mathrm{NADP}^{+}, 1 \mathrm{mM}$ ATP and $1 \mathrm{U}$ glucose-6-phosphate dehydrogenase.

Phosphofructokinase (PFK; E.C. 2.7.1.11) $50 \mathrm{mM}$ imidazole (pH 7.0), $50 \mathrm{mM} \mathrm{KCl}, 5 \mathrm{mM} \mathrm{MgCl} 2,1 \mathrm{mM}$ ATP, $1 \mathrm{mM}$ fructose-6-phosphate, $0.15 \mathrm{mM}$ $\mathrm{NADH}$ and $1 \mathrm{U}$ each of aldolase, glycerol-3-phosphate dehydrogenase and triosephosphate isomerase.

Aldolase (ALD; E.C. 4.1.2.13) : $50 \mathrm{mM}$ imidazole buffer (pH 7.0), $2 \mathrm{mM}$ $\mathrm{MgCl}_{2}, 0.2 \mathrm{mM}$ fructose 1,6-bisphosphate, $0.15 \mathrm{mM} \mathrm{NADH}, 1 \mathrm{U}$ of triosephosphate isomerase and $2 U$ of glycerol-3-phosphate dehydrogerase. Glycerol-3-phosphate dehydrogenase (G3PDH; E.C. 1.1.1.8) : $50 \mathrm{mM}$ Tris

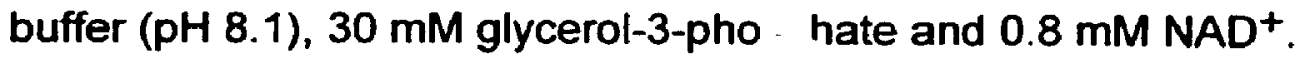
Pyruvate kinase (PK; E.C. 2.7.1.40) : $50 \mathrm{mM}$ imidazole (pH 7.0), $50 \mathrm{mM} \mathrm{KCl}$, $5 \mathrm{mM} \mathrm{MgCl}_{2}, 2 \mathrm{mM}$ phosphoenolpyruvate, $0.15 \mathrm{mM} \mathrm{NADH}, 1 \mathrm{mM}$ ADP, $0.2 \%$ (v/v) rotenone saturated ethanol and $2 U$ lactate dehydrogenase.

Lactate dehydrogenase (LDH; E.C. 1.1.1.27) : $50 \mathrm{mM}$ imidazole buffer (pH7.0), $2 \mathrm{mM} \mathrm{MgCl} 2,2 \mathrm{mM}$ pyruvate, $0.15 \mathrm{mM}$ NADH.

Pyruvate dehydrogenase (PDH; E.C. 1.2.4.1) activities were measured as previously described (Elnageh and Gaitonde 1988) using a colorimetric assay with aminophenylazobenzene sulphonic acid (AABS) as the dye reagent. Both active a and total $(\underline{a}+\underline{b})$ activities were monitored at $460 \mathrm{~nm}$ on a Gilford 250 spectrophotometer. Each assay contained $50 \mathrm{mM}$ tris buffer, $\mathrm{pH}$ 7.8, $1 \mathrm{mM} \mathrm{MgCl} 2,0.25 \mathrm{mM}$ EDTA, $0.4 \% \mathrm{v} / \mathrm{v}$ Triton $\mathrm{X}-100,10 \mathrm{mM}$ pyruvate, 5 mM NAD+, $2 \mathrm{mM}$ cocarboxylase, $1 \mathrm{mM}$ coenzyme $A$ and $1 \mathrm{U}$ arylamine transferase in a volume of $1 \mathrm{ml}$. Nonspecific activity measured in the absence of pyruvate was subtracted for each determination. 
5'-Nucleotidase (5NT; E.C. 3.1.3.5) : $20 \mathrm{mM}$ imidazole buffer (pH 7.0), $500 \mathrm{mM} \mathrm{MgSO} 4,3 \mathrm{mM}$ AMP, $0.15 \mathrm{mM} \mathrm{NADH}, 2.5 \mathrm{mM}$ 2-oxoglutarate and $2 \mathrm{U}$ each of glutamate dehydrogenase and adenosine deaminase.

Adenylate kinase (ADK; E.C. 2.7.4.3) : $50 \mathrm{mM}$ potassium phosphate buffer (pH 7.4), $500 \mathrm{mM} \mathrm{MgSO}_{4}, 200 \mathrm{mM} \mathrm{KCl}, 2 \mathrm{mM}$ AMP, $0.15 \mathrm{mM} \mathrm{NADH}, 2 \mathrm{mM}$ ATP, $2 \mathrm{mM}$ phosphoenolpyruvate and $2 U$ each of lactate dehydrogenase and pyruvate kinase.

ATP-citrate lyase (ATPCL; E.C. 4.1.3.8) : $200 \mathrm{mM}$ tris/HCl buffer (pH 8.4), $10 \mathrm{mM}$ B-mercaptoethanol, $0.2 \mathrm{mM}$ CoA, $0.15 \mathrm{mM} \mathrm{NADH}, 10 \mathrm{mM} \mathrm{MgCl} 2$. $20 \mathrm{mM}$ potassium citrate, $10 \mathrm{mM}$ ATP (in a 1:1 molar ratio with $\mathrm{MgCl}_{2}$ ) and $1 \cup$ malate dehydrogenase.

Fatty acid synthetase (FAS) $100 \mathrm{mM}$ potassium phosphate buffer (pH 7.0), $3 \mathrm{mM}$ EDTA, $5 \mathrm{mM}$ dithiothreitol, $0.05 \mathrm{mM}$ malonyl-CoA, $0.032 \mathrm{mM}$ acetyl-CoA, $0.3 \mathrm{mM} \mathrm{NADPH}$ and $0.2 \%(\mathrm{~V} / \mathrm{v})$ rotenone saturated ethanol. Isocitrate dehydrogenase (NADP+ dependent) (NADPIDH; E.C. 1.1.1.42) : $50 \mathrm{mM}$ imidazole buffer $(\mathrm{pH} 8.1), 5 \mathrm{mM} \mathrm{MgCl} 2,6 \mathrm{mM}$ isocitrate and $0.4 \mathrm{mM}$ $\mathrm{NADP}^{+}$.

Glucose-6-phosphate dehydrogenase (G6PDH; E.C. 1.1.1.49) : $60 \mathrm{mM}$ tris buffer ( $\mathrm{pH} 7.5$ ), $3.3 \mathrm{mM}$ glucose-6-phosphate, $0.4 \mathrm{mM} \mathrm{NADP}+$ and $6 \mathrm{mM}$ $\mathrm{MgCl}_{2}$.

6-Phosphogluconate dehydrogenase (6PG; E.C. 1.1.1.43) : $50 \mathrm{mM}$ tris/HCI buffer (pH 7.0), 0.5 mM 6-phosphogluconate, 0.4 mM NADP+ Malate dehydrogenase (NAD+ dependent) (NADMDH; E.C. 1.1.1.37) : $50 \mathrm{mM}$ imidazole buffer, $10 \mathrm{mM} \mathrm{MgCl} 2,10 \mathrm{mM}$ oxaloacetate, $0.15 \mathrm{mM}$ NADH. 
Malate dehydrogenase (NADP+ dependent) (NADPMDH; E.C. 1.1.1.37) :

$50 \mathrm{mM}$ imidazole buffer, $10 \mathrm{mM} \mathrm{MgCl} 2,6 \mathrm{mM}$ oxaluacetate, $0.15 \mathrm{mM}$ NADPH.

Malic enzyme (ME; E.C. 1.1.1.40) : $75 \mathrm{mM}$ triethanılamine buffer ( $\mathrm{pH} 7.4$ ), $4 \mathrm{mM} \mathrm{MnCl}_{2}, 0.5 \mathrm{mM} \mathrm{L-mz:ate,} 0.2 \mathrm{mM} \mathrm{NADP+}$.

Carnitine octanoyltransferase (COT; E.C. 2.3.1.21) : $50 \mathrm{mM}$ imidazole buffer (pH 8.1), $0.2 \%(\mathrm{v} / \mathrm{v})$ Triton X-100, $5 \mathrm{mM}$ L-carnitine, $50 \mu \mathrm{M}$


activity was monitored at $410 \mathrm{~nm}$.

Carnitine palmitoyltransferase (CPT; E.C. 2.3.1.21) : $50 \mathrm{mM}$ imidazole buffer (pH 8.1), $0.2 \%(v / v)$ Triton X-100, $5 \mathrm{mM}$ L-carnitine, $50 \mu \mathrm{M}$ palmitoyl-CoA and $0.1 \mathrm{mM}$ DTNB. Enzyme activity was monitored at $410 \mathrm{~nm}$. 3-Hydroxyacyl-CoA dehydrogenase (HOAD; E.C. 1.1.1.35) : $50 \mathrm{mM}$ imidazole buffer (pH 8.0), $0.1 \mathrm{mM}$ acetoacetyl-CoA and $0.1 \mathrm{mM} \mathrm{NADH}$. B-Hydroxybutyrate dehydrogenase (BDH; E.C. 1.1.1.30) :50 mM imidazole buffer (pH 8.1), $20 \mathrm{mM}$ B-hydroxybutyrate and $0.4 \mathrm{mM} \mathrm{NAD+}$. Glutamate dehydrogenase (GDH; E.C. 1.4.1.2) : $100 \mathrm{mM}$ triethanolamine buffer (pH 8.0), 5 mM EDTA, $200 \mathrm{mM}$ ammonium carbonate, $7.5 \mathrm{mM}$ 2-oxoglutarate, $0.15 \mathrm{mM} \mathrm{NADH}$ and $1 \mathrm{mM}$ ADP.

Branched chain ketoacid dehydrogenase (KADH) : $30 \mathrm{mM}$ potassium phosphate buffer (pH 7.5), $2 \mathrm{mM} \mathrm{MgCl} 2,1 \mathrm{mM}$ dithiothreitol, $0.1 \%(\mathrm{v} / \mathrm{v}$ ) Triton $\mathrm{X}-100,2 \mathrm{mM}$ ketoisovalerate, $0.2 \mathrm{mM} \mathrm{NAD}+, 0.4 \mathrm{mM}$ cocarboxy,ase, $0.4 \mathrm{mM}$ CoA and $10 \mathrm{U}$ lipoamide dehydrogenase.

Serine dehydratase (SDH; E.C. 4.2.1.13) : $200 \mathrm{mM}$ potassium phosphate buffer (pH 8.0), $2 \mathrm{mM}$ EDTA, $100 \mathrm{mM}$ L-serine, $0.11 \mathrm{mM}$ pyridoxal phosphate, $0.15 \mathrm{mM} \mathrm{NADH}, 0.2 \%(\mathrm{v} / \mathrm{v})$ rotenone saturated ethanol, and $1 \mathrm{U}$ lactate dehydrogenase. 
Aspartate aminotransferase (ASPAT; E.C. 2.6.1.1) : $500 \mathrm{mM}$ imidazole buffer (pH 7.8), $30 \mathrm{mM}$ B-mercaptoethanol, $15 \mathrm{mM}$ 2-oxoglutarate, $250 \mathrm{mM}$ L-aspartate, $0.11 \mathrm{mM}$ pyridoxal phosphate, $0.15 \mathrm{mM} \mathrm{NADH}$ and $1 \mathrm{U}$ of malate dehydrogenase (NAD ${ }^{+}$dependent).

Alanine aminotransferase (ALAT; E.C. 2.6.1.2) : $500 \mathrm{mM}$ imidazole buffer (pH 7.3), $30 \mathrm{mM}$ B-mercaptoethanol, $15 \mathrm{mM}$ 2-oxoglutarate, $500 \mathrm{mM}$ L-alanine, $0.11 \mathrm{mM}$ pyridoxal phosphate, $0.15 \mathrm{mM} \mathrm{NADH}$ and $1 \mathrm{U}$ lactate dehydrogenase.

Fructose-1,6-bisphosphatase (FBPase; E.C. 3.1.3.11) : $25 \mathrm{mM}$ imidazole buffer ( $\mathrm{pH} 8.0$ ), $5 \mathrm{mM} \mathrm{MgSO}_{4}, 0.2 \mathrm{mM} \mathrm{NADP}^{+}, 2.8 \mathrm{mM}$ fructose-1,6-bisphosphate and $1 U$ each of glucose-6-phosphate dehydrogenase and phosphoglucose isomerase.

Phosphoenolpyruvate carboxykinase (PEPCK; E.C. 4.1.1.32) : $100 \mathrm{mM}$ imidazole buffer (pH 6.6), $6 \mathrm{mM}$ B-mercaptoethanol, $50 \mathrm{mM}$ sodium bicarbonate, $1.2 \mathrm{mM}$ phosphoenolpyruvate, $1.25 \mathrm{mM}$ inosine diphosphate, $1 \mathrm{mM} \mathrm{MnCl}_{2}, 0.15 \mathrm{mM} \mathrm{NADH}$ and $2.5 \mathrm{U}$ malate dehydrogenase (NAD+ dependent). All solutions were degassed prior to assay. Isocitrate dehydrogenase (NAD+ dependent) (NADIDH; E.C. 1.1.1.41) : same as the NADP ${ }^{+}$dependent except $0.4 \mathrm{mM} \mathrm{NAD}^{+}$replaces NADP ${ }^{+}$and $2 \mathrm{mM}$ ADP was included in the assay mixture.

Ketoglutarate dehydrogenase (KGDH; E.C. 1.2.4.2) : $50 \mathrm{mM}$ imidazole buffer ( $\mathrm{pH} 7.5$ ), $0.75 \mathrm{mM}$ ketoglutarate, $0.4 \mathrm{mM} \mathrm{NAD}^{+}, 2 \mathrm{mM}$ cocarboxylase, $0.1 \mathrm{mM} \mathrm{CoA}$ and $0.2 \%(\mathrm{v} / \mathrm{v})$ rotenone saturated ethanol. Citrate synthase (CS; E.C. 4.1.3.7) : $50 \mathrm{mM}$ imidazole buffer (pH 8.1), $0.2 \%$ (v/v) Triton X-100, $1 \mathrm{mM}$ oxaloacetate, $0.1 \mathrm{mM}$ acetyl-CoA and $0.1 \mathrm{mM}$ DTNB. Enzyme activity was monitored at $410 \mathrm{~nm}$. 
Protein concentration was determined by the Bio-Rad assay kit (Coomassie blue G-250 binding method; Bradford 1976) with bovine serum albumin as the standard. Spectrophotometric quantification was performed at $595 \mathrm{~nm}$ using a Dynatech MR-5000 microplate reader in a final well volume of $310 \mu$.

Enzyme activity assays were interpreted by use of the MPA program (Brooks 1994). All values were compared by two tailed Student t-tests. Significant differences were determined at the $\mathrm{P}<0.005$ and $\mathrm{P}<0.05$ levels. 


\section{Results}

Table 2.1 is a compilation of homogenization factors for each tissues and the corresponding soluble protein concentration in $\mathrm{mg}$ per $\mathrm{ml}$. Also shown is the conversion factor for the determination of $\mathrm{mU} / \mathrm{gram}$ wet weight from U/mg soluble protein for the enzyme data of all other tables and figures. There were no significant differences in soluble protein content between hibernating and euthermic tissues.

Figures 2.1-2.5 show the hibernation induced changes in activities of enzymes in liver, kidney, heart, skeletal muscle and white adipose tissue (WAT), respectively. Enzyme activities that did not change during hibernation are listed in the corresponding Figure. Enzymes in the five figures are grouped into three sections as follows:

(a) glycolysis: ri'ucokinase (GK), hexokinase (HK), phosphofructokinas' (PFK), aldolase (ALD), glycerol-3-phosphate dehydrogenase (G3PDH), pyruvate kinase (PK), lactate dehydrogenase (LDH);

(b) Fatty acid catabolism and synthesis: 3-hydroxyacyl-CoA dehydrogenase (HOAD), $B$-hydroxybutyrate dehydrogenase (BDH), carnitineoctanoyl tranferase (COT), carnitine-palmitoyl transferase (CPT), ATP-citrate lyase (ATPCI), fatty acid synthetase (FAS), glucose-6-phosphate dehydrogenase (G6PDH), 6-phosphogluconate dehydrogenase (6PGDH), (NADP+ dependent) malate dehydrogenase (NADPMDH), malic enzyme (ME), (NADP+ dependent) isocitrate dehydrogenase (NADPIDH); and 
(c) amino acid catabolism, gluconeogenesis and TCA cycle: glutamate dehydrogenase (GDH), branched chain ketoacid dehydrogenase (KADH), serine dehydratase (SDH), aspartate aminotransferase (ASPAT), alanine aminotransferase (ALAAT), fructose-bisphosphatase (FBPase), phosphoenolpyruvate carboxykinase (PEPCK), (NAD+ dependent) isocitrate dehydrogenase (NADIDH), $\alpha$-ketoglutarate dehydrogenase (KGDH), (NAD+ dependant) malate dehydrogenase (NADMDH) and citrate synthase (CS).

Among the enzymes of glycolysis, relatively few enzyme activities showed significant changes during hibernation. In liver, only LDH activity changed, but the effect was substantial, LDH increasing 2-fold in the tissue from the hibernator. Kidney demonstrated no change in enzyme activities associated with glycolysis during hibernation. In heart however, LDH activity decreased $5 \%$ during hibernation whereas aldolase activity rose by $30 \%$. Skeletal muscle also showed reduced LDH activity during hibernation, dropping to $40 \%$ of the control euthermic values. Hexokinase activity was also reduced significantly in skeletal muscle during hibernation, falling to $80 \%$ of control. WAT showed a considerable reorganization during hibernation; both hexokinase and aldolase activities fell to $70 \%$ of control values whereas G3PDH activity increased 4-fold during hibernation.

PDH activity was detected only in kidney and heart extracts (Figure 2.6). Hibernation had no effect on total enzyme activity, but the percentage of the enzyme in the active form fell dramatically in both tissues during hibernation indicating this as a major locus in the control of glycolytic carbon 
flow into the TCA cycle. In all of the other tissues tested, PDH activity was below the limits of detection, likely a result of low mitochondrial numbers.

The most prominent changes in enzyme activities associated with fatty acid metabolism were seen in the liver. Maximal activities of COT and CPT, which are rate limiting in B-oxidation both increased 3-fold during hibernation. ATPCL, an enzyme associated with fatty acid synthesis was suppressed during hibernation, however FAS activity increased by $10 \%$ relative to control levels. Two other enzymes associated with fatty acid synthesis showed significant changes in activity, G6PDH and NADPIDH, both of which decreased to $40 \%$ of control values during hibernation. Kidney demonstrated similar changes, with levels of G6PDH and NADPIDH decreasing 2-fold during hibernation. However, ME activity in this tissue increased 2-fold relative to control levels. Heart was another tissue in which enzymes utilizing $\mathrm{NADP}^{+}$as a cofactor decreased during hibernation. Both NADPMDH and NADPIDH activities decreased to $50 \%$ of control values during hibernation. In skeletal m'jscle, COT activity iricreased by $30 \%$ in hibernatirg tissues, whereas levels of G6PDH rose 3-fold. ME activity in this tissue decreased, to $80 \%$ of control levels.

Enzyme activities associated with amino acid metabolism generally showed no strong changes during hibernation. In the liver, GDH increased slightly $(<5 \%)$ during hibernation, however decreases in activity were seen for ASPAT (10\%) and ALAAT (25\%) and SDH which was undetected in hibernating tissues. In kidney, GDH and ASPAT levels decreased $25 \%$ and ALAAT activity decreased $70 \%$ whereas $\mathrm{KADH}$ activity increased 2-fold. In heart extracts, a single enzyme activity changed, ASPAT, which increased 
approximately $30 \%$, whereas in WAT, this activity decreased $20 \%$ during hibernation. There were no changes in skeletal muscle activities associated with amino acid metabolism.

Gluconeogenic enzyme activities were represented by FBPase and PEPCK. In kidney of hibernators, there was a strong suppression of both activities, 10-fold for FBPase and 3-fold for PEPCK. Conversely, FBPase activity increased by approximately $30 \%$ in heart and muscle. During hibernation, there were no gluconeogenic enzyme changes in liver or WAT.

Four enzymes associated with TCA cycle flux were tested. These were CS, NADIDH, KGDH and NADMDH. The low activities of the enzymes KGDH and NADIDH relative to the other TCA cycle enzymes tested demonstrate their regulatory role. NADIDH increased in liver (3-fold), kidney (2-fold) and heart (2-fold) during hibernation, however in muscle, activity did not change. Conversely, KGDH increased in hibernator muscle extracts (being undetectable in controls), whereas $\mathrm{KGDH}$ activities were constant in all other tissues. 


\section{Discussion}

Table 2.3 is a compilation of probable shifts in the importance of metabolic flux through different pathways in organs of hibernating relative to euthermic S. lateralis and provides for the majority of the observations noted herein. Increases or decreases in metabolic flux potential in a given pathway were determined by either a general increase or suppression of enzyme activities during hibernation. In pathways winere no obvious trend was observed, the symbol ' $\because$ ' was inserted.

\section{Liver}

The liver is one of the most metabolically active tissues and demonstrated the greatest changes in enzyme activity in this study. During hibernation, ketones generated from the catabolism of lipids are synthesized primarily in the liver and are then circulated to other tissues (see Chapter 3 ). The catabolism of lipids is regulated by the enzymes COT and CPT both of which increased in activity during hibernation. Not unexpectedly, there was a reduction in the production of NADPH during hibernation, indicating a disparity in biosynthetic processes. This was a common trend throughout all the tissues tested. There were no prominent changes in liver glycolytic enzyme activities with the exception of LDH. Previous studies showed that glycolytic flux is suppressed during hibernation by various other mechanisms, which include changes in the phosphorylation state of enzymes (for example PFK, PK in Zapus hudsonius; Storey 1987a; Storey 1987b), and changes in the concentrations of effectors (for example fructose 2,6-bisphosphate; Brooks and Storey 1992). This was reflected in the relatively few changes in enzyme maximal activities detected in this and other tissues tested. 
Furthermore, PFK and PK maximal activities, the two major regulatory sites of glycolysis did not change during hibernation in any tissue. Changes in enzyme activities associated with amino acid catabolism demonstrated a decreased potential for use of protein as metabolic substrate during hibernation in liver in accordance with increased mobilization of lipid substrate.

\section{Kidney}

The kidney is another highly active tissue, however there were no changes in glycolytic enzyme activities during hibernation. Furthermore, there were no changes in the total activity of PDH, although a sharp suppression of the active a form demonstrated that this was a major locus in the control of carbohydrate flow into the TCA cycle during hibernation. Enzymes of fatty acid catabolism were unchanged, however enzyme activities involved in NADPH production for fatty acid biosynthesis were largely reduced during hibernation. In accordance with liver, amino acid catabolism was reduced and in addition, gluconeogenic enzyme activities were suppressed during hibernation.

\section{Heart}

Enzyme activities associated with glycolysis and fatty acid metabolism in the heart showed no obvious trends, however, maximal activities of gluconeogenic and TCA cycle enzymes increased during hibernation. ASPAT was the only enzyme activity in amino acid catabolism to change, and increased during hibernation. The reason for the latter is unclear, however for reasons mentioned earlier, the pathway of protein degradation is likely governed by substrate availability. PDH was also present in this tissues and 
as was the case for kidney, the active a form of the enzyme was dramatically suppressed during hibernation.

Skeletal muscle

Activities of glycolytic enzymes in skeletal muscle generally decreased during hibernation, complemented by an increase in activities of $B$-oxidation enzymes. However, the potential for maximum flux through the TCA cycle. gluconeogenesis and the pentose phosphate shunt all increased during hibernation. It is likely that these pathways are actively maintained for rapid activation of shivering thermogenesis during arousal.

WAT

WAT is one of the least metabolically active tissues, due to its relatively low protein content. As a result, many enzymes were below the detection limits of the assays used in this study. The most prominent changes were observed with enzymes of glycolysis, where hexokinase and aldolase activities decreased, while G3PDH activity increased. This may indicate a trend towards inclusion of glycerol-3-phosphate derived from triglyceride catabolism into glycolysis relative to the use of glucose. Malic enzyme activity decreased during hibernation which may be the result of reduced fatty acid synthesis, and as well, levels of ASPAT decrease reducing the potential for amino acid catabolism.

There were several prominent trends throughout the tissues tested. Changes in glycolytic enzyme activities generally showed a trend towards a reduction in glycolytic potential during hibernation. However, this was not the case for liver, which only had changes in LDH activity. TCA cycle enzyme activities showed a general increase throughout the tissues tested, however, 
tnis pathway is severely limited in its use of carbohydrate substrate in both kidney and heart by the strong suppression of PDH activity. As a result, an alternate source of carbon must be employed. The two enzy'mes COT and CPT generally increased in activity during hibernation, providing an increased potential flux for B-oxidation of fatty acids. CPT is strongly regulated by the effector malonyl-CoA, however this data suggests that a change in the concentration of the enzyme also plays a prominent role in regulating fatty acid oxidation. Another trend was evident for the enzymes (NADP+) IDH, (NADP+) MDH, malic enzyme, G6PDH and 6PGDH which are generally suppressed during hibernation. This indicates a decreased potential for production of NADPH and likely functions to limit biosynthetic processes during hibernation. 
Table 2.1. Soluble protein concentrations of $S$. lateralis tissues in terms of $\mathrm{mg} / \mathrm{ml}$ and the corresponding multiplication factor for conversion of $\mathrm{mU} / \mathrm{mg}$ soluble protein to IU/gram wet weight of tissue. There was no difference in protein content between tissues from hibernating and euthermic animals. All data is presented as means \pm SEM and are the mean of 8 separate preparations.

Tissue $\begin{array}{ccc}\text { extraction } & \mathrm{mg} \text { soluble protein } & \mathrm{mU} / \mathrm{gww}: \mathrm{IU} / \mathrm{gmw} \\ \text { dilution } & \text { per } \mathrm{ml} \text { tissue extract } & \text { conversion factor }\end{array}$

liver

6

$43.66 \pm 3.12$

0.26

heart

6

$29.15 \pm 1.37$

0.17

kidney

6

$26.84 \pm 1.98$

0.16

muscle

6

$16.92 \pm 1.46$

0.10

WAT

6

$4.55 \pm 0.44$

0.027 
Table 2.2. Maximal enzyme activities that were maintained in S. lateralis tissues during hibernation. Enzyme maximal activities are classified as outlined in the Results section. All values are presented as means \pm SEM and are the mean of $6-10$ preparations.

liver

(a)

HK

Aldolase

PFK

G3PDH

PK

(b)

HOAD
BDH
6PGDH
(NADP) MDH
ME
NADPIDH

(c)

$\mathrm{KADH}$

FBPase

PEPCK

NADIDH

(NAD) MDH

CS
$\mathrm{mU} / \mathrm{mg}$ soluble protein

$2.89 \pm 0.15$

$21.3 \pm 1.8$

$118.9 \pm 5.8$

$14.2 \pm 1.4$

$38.2 \pm 1.6$

$53.6 \pm 12.2$

$26.7 \pm 5.5$

$8.56 \pm 2.48$

$30.7 \pm 3.6$

$17.5 \pm 1.4$

$4.11 \pm 0.30$

$2.36 \pm 0.08$

$23.3 \pm 1.4$

$12.0 \pm 0.8$

$0.30 \pm 0.05$

$9.17 \pm 1.28$

$43.8 \pm 2.3$ kidney

(a)

HK

PFK

Aldolase

G3PDH

LDH

PK

(b)

HOAD

COT

CPT

FAS

6PGDH

(NADP) MDH

(c)

$\mathrm{KGDH}$

CS
$\mathrm{mU} / \mathrm{mg}$ soluble protein

$$
\begin{gathered}
7.23 \pm 0.51 \\
373.6 \pm 38.9 \\
22.1 \pm 2.2 \\
10.5 \pm 0.8 \\
2704.3 \pm 116.9 \\
39.6 \pm 2.02
\end{gathered}
$$

$53.4 \pm 15.5$

$13.5 \pm 1.3$

$0.75 \pm 0.18$

$0.08 \pm 0.03$

$6.77 \pm 2.23$

$89.0 \pm 10.1$

$2.27 \pm 0.18$

$74.9 \pm 5.6$ 
Table 2.2 continued,

heart

(a)

$\begin{array}{lc}\text { HK } & 6.92 \pm 0.30 \\ \text { PFK } & 286.2 \pm 13.4 \\ \text { G3PDH } & 1.44 \pm 0.13 \\ \text { PK } & 281.1 \pm 0.3\end{array}$

(b)

HOAD

COT

FAS

G6PDH

EPGDH

ME

(c)

$\mathrm{GDH}$

$\mathrm{KADH}$

ALAAT

PEPCK

$\mathrm{KGDH}$

CS

WAT

(a)

PFK

PK

$\mathrm{LDH}$

(b)

G6PDH

(c)

GDH

ALAAT

FBPase

CS
$\mathrm{mU} / \mathrm{mg}$ soluble protein

$42.8 \pm 17.3$

$17.8 \pm 2.2$

$0.25 \pm 0.06$

$1.70 \pm 0.25$

$2.16 \pm 0.45$

$1.42 \pm 0.09$

$297.0 \pm 19.9$

$1.70 \pm 0.30$

$13.76 \pm 1.05$

$3.75 \pm 0.24$

$1.84 \pm 0.15$

$308.4 \pm 28.6$
$1.72 \pm 0.18$

$1.63 \pm 0.10$

$238.0 \pm 34.8$

$8.26 \pm 0.91$

$13.06 \pm 1.69$

$24.07 \pm 2.98$

$2.78 \pm 0.20$

$14.82+3.36$ skeletal muscle

(a)

PFK

Aldolase

G3PDH

PK

(b)

HOAD

CPT

6PGDH

(NADP) $\mathrm{MDH}$

NADPIDH
$\mathrm{mU} / \mathrm{mg}$ soluble protein

$$
973.7 \pm 72.6
$$

$141.0 \pm 11.1$

$7.67 \pm 0.48$

$215.9 \pm 0.6$

$25.3 \pm 23.7$

$2.25 \pm 0.34$

$3.94 \pm 2.17$

$105.4 \pm 6.2$

$37.9 \pm 3.8$

(c)

GDH

SDH

$3472.8 \pm 132.9$

ASPAT

ALAAT

PEPCK

NADIDH

CS
$1.05 \pm 0.11$

$1737.9 \pm 138.0$

$590.5 \pm 60.3$

$12.03 \pm 0.83$

$0.87 \pm 0.12$

$136.4 \pm 20.8$ 
Table 2.3. Trends observed in metabolic pathways during hibernation relative to euthermia. Arrows denote estimated increases or decreases in flux potential determined from general trends observed with enzyme activities. Enzyme activities that were not detected in a particular pathway are denoted by nd while those denoted by the symbol ' $\because$ demonstrated no obvious trends.

Metabolic pathway

glycolysis

PDH

fatty acid catabolism

NADPH production (biosynthesis)

protein catabolism

gluconeogenesis

TCA cycle liver heart kidney muscle WAT

$\begin{array}{ccccc}\Uparrow & \Uparrow & \div & \Downarrow & \div \\ \text { nd } & \Downarrow & \Downarrow & \text { nd } & \text { nd } \\ \Uparrow & \div & \div & \Uparrow & \text { nd } \\ \Downarrow & \Downarrow & \Downarrow & \div & \Downarrow \\ \Downarrow & \Uparrow & \div & \div & \Downarrow \\ \div & \Uparrow & \Downarrow & \Uparrow & \div \\ \Uparrow & \Uparrow & \Uparrow & \Uparrow & \text { nd }\end{array}$


Figures 2.1 to 2.5. Maximal enzyme activities in tissues of hibernating and euthermic $S$. lateralis expressed as $\mathrm{mU} / \mathrm{mg}$ soluble protein. For each tissue, enzyme activities were placed in groups (a), (b) or (c) as outlined in the Results section and includes a list of enzyme activities that were not detected in either hibernating or euthermic tissues. For all graphs, open boxes represent euthermic tissue extracts; hatched boxes represent hibernating tissue extracts. Superscript $a$ and $b$ denote significant differences from control at the $\mathrm{P}<0.005$ and $\mathrm{P}<0.05$ levels respectively. nd denoted enzyme activities that were not detected. All results are the mean of 3-5 determinations on separate tissues preparations; error bars represent SEM. 
Figure 2.1. Maximal enzyme activities in liver extracts. Activities that were not detected in either euthermic or hibernating extracis were GK and KGDH. 
specific activity ( $\mathrm{mU} / \mathrm{mg}$ protein)




Figure 2.2. Relative enzyme activities in kidney extracts. Activities that were not detected in either euthermic or hibernating extracts were GK and BDH. 
specific activity ( $\mathrm{mU} / \mathrm{mg}$ protein)
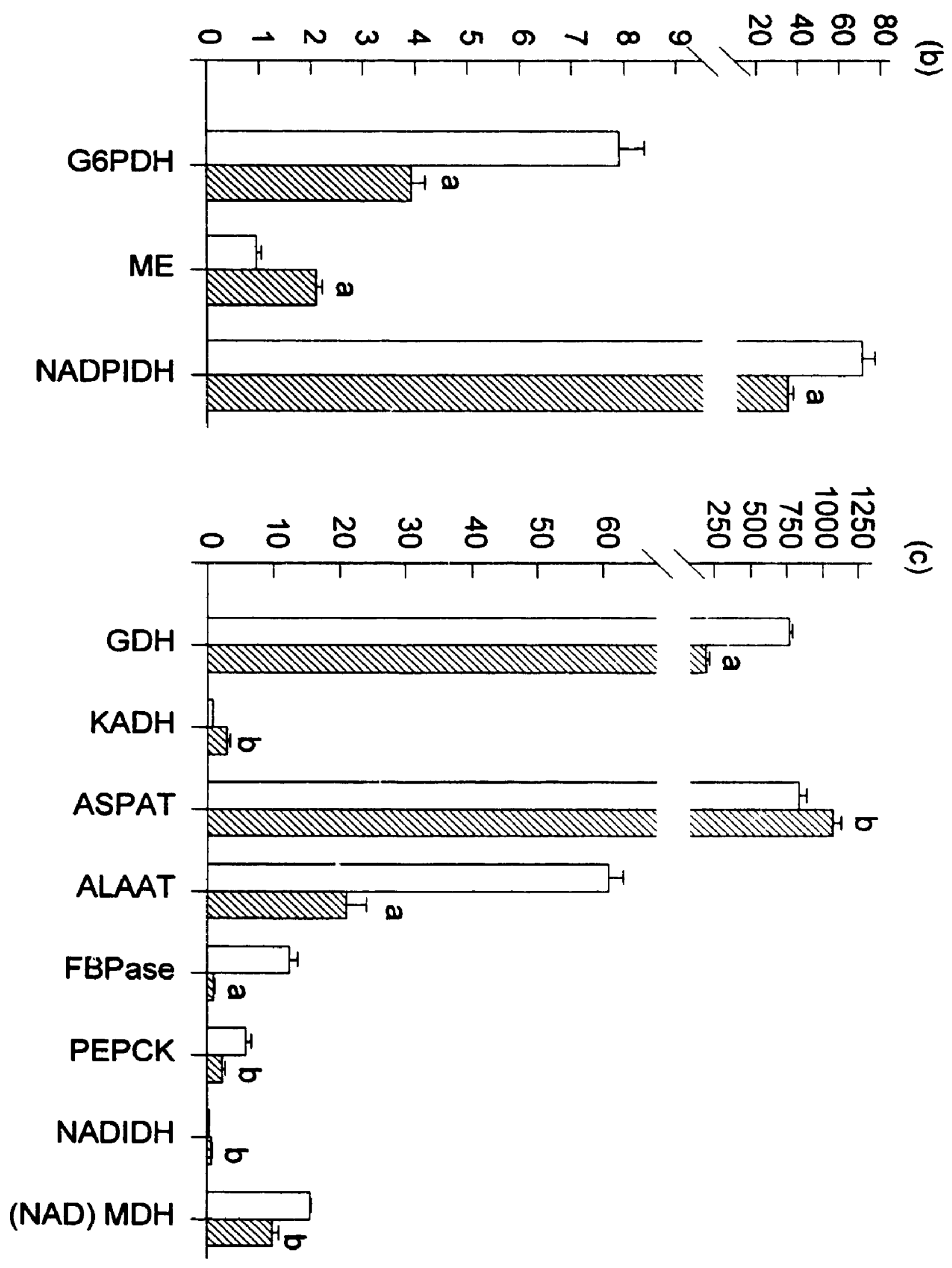
Figure 2.3. Relative enzyme activities in heart extracts. Activities that were not detected in either euthermic or hibernating extracts were GK, BDH, CPT, ATPCl and SDH. 
specific activity (mU/mg protein)

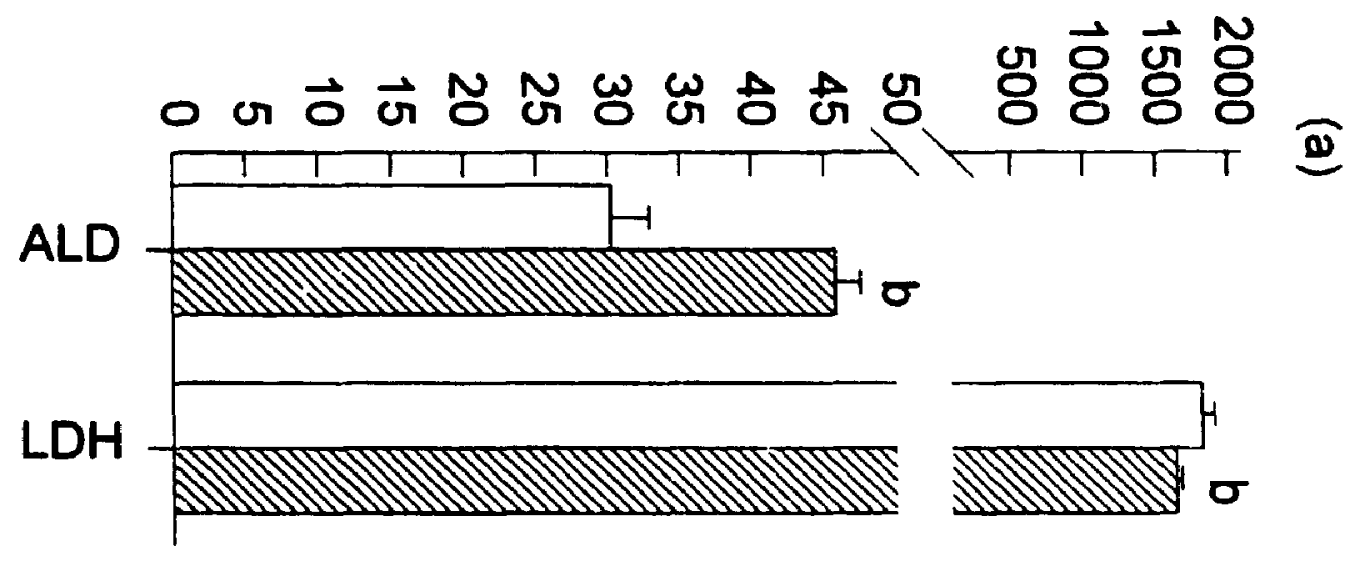

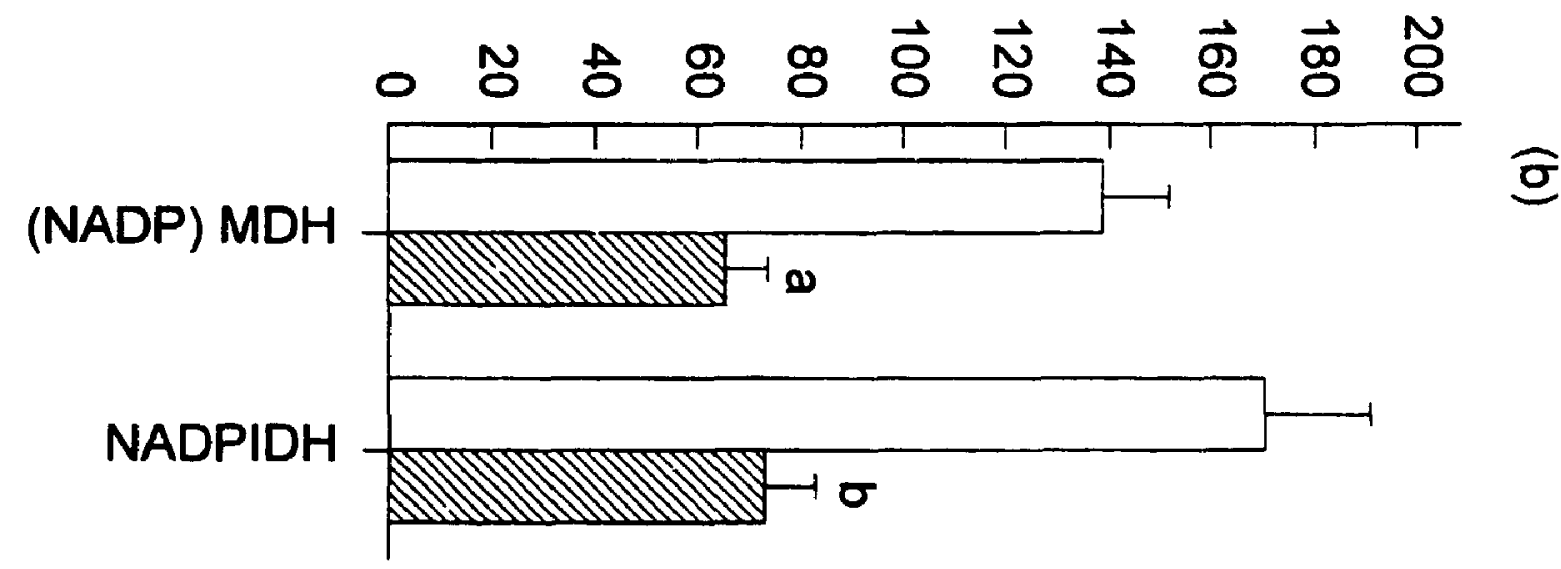

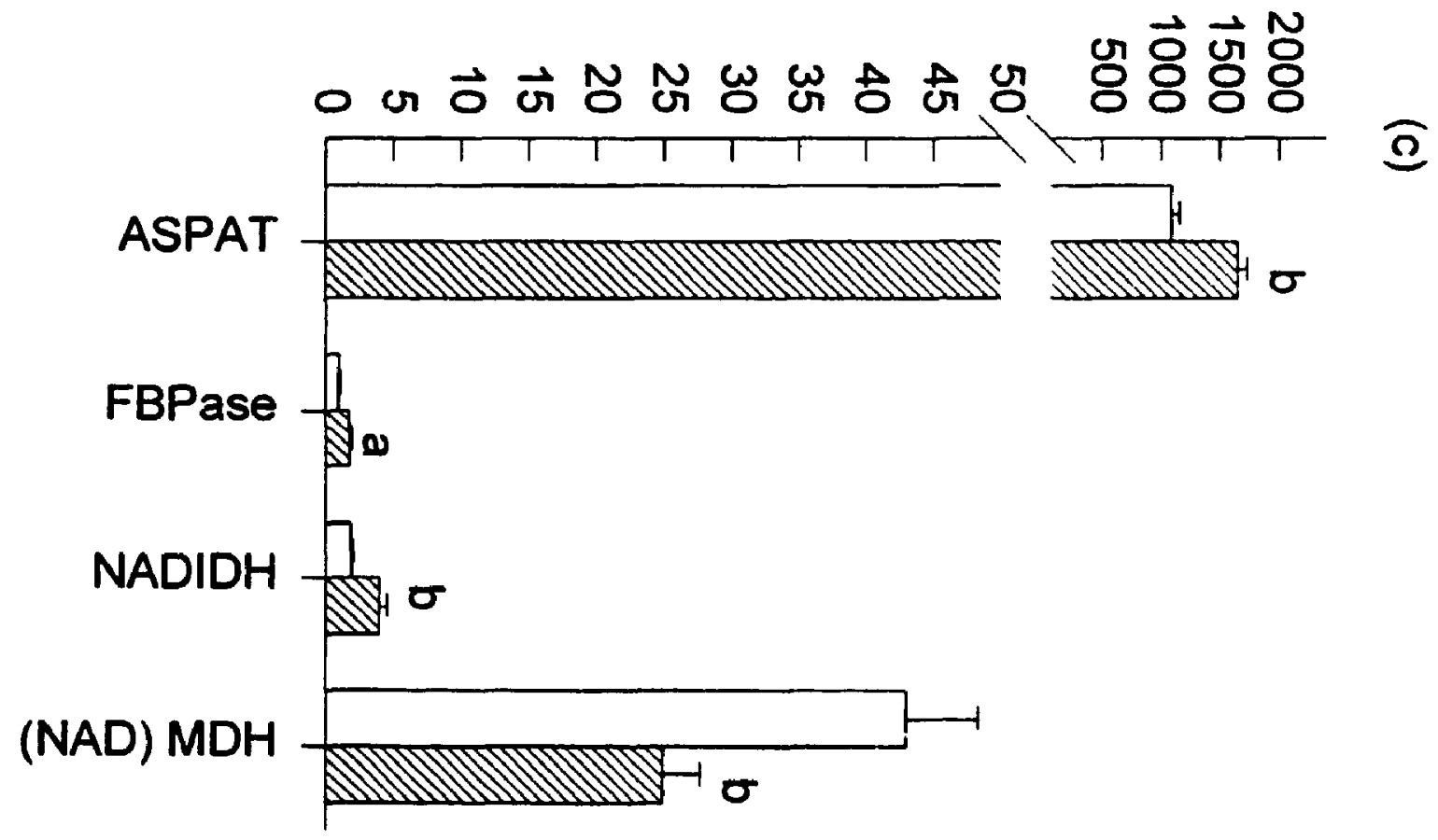


Figure 2.4. Relative enzyme activities in muscle extracts. Activities that were not detected in either euthermic or hibernating extracts were GK, BDH, KADH and SDH. 


\section{specific activity (mU/mg protein)}
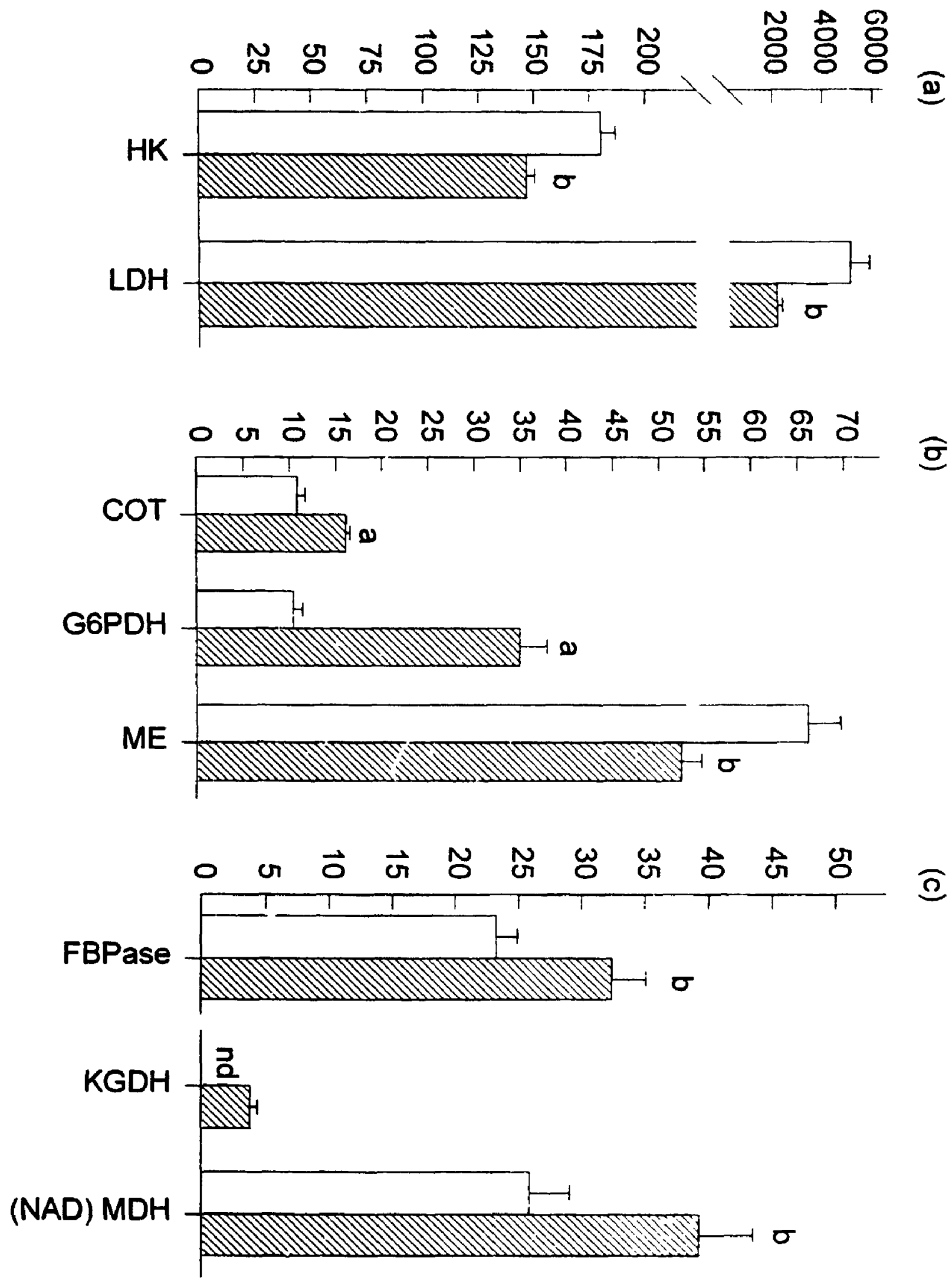
39

Figure 2.5. Relative enzyme activities in WAT extracts. Activities that were not detected in either euthermic or hibernating extracts were GK, HOAD, BD, COT, CPI, IAS, 6PGDH, NADPMDH, NADPIDH, KAPH, SD, PEPCK, NADIDH, KGNH, and NADMDH. 


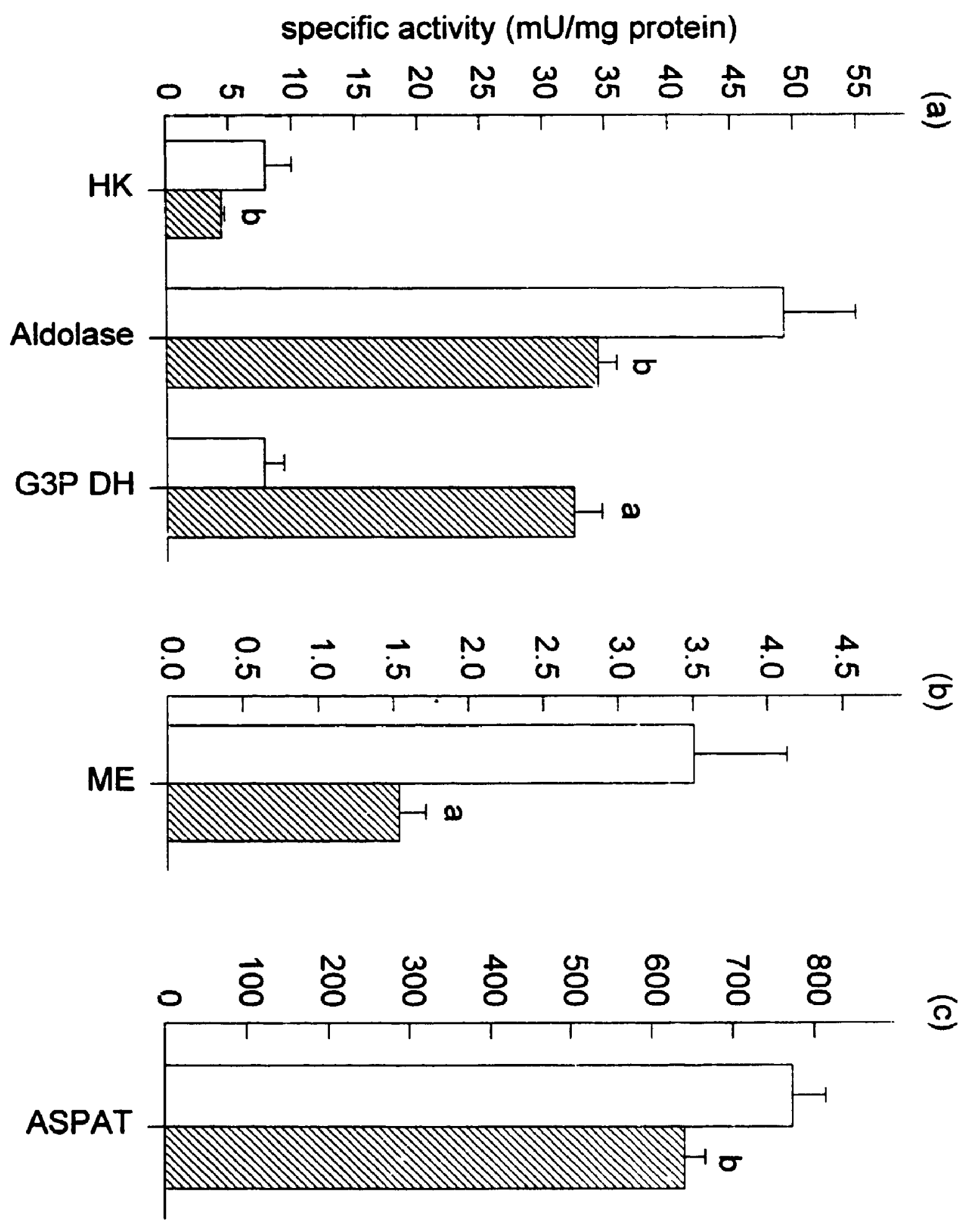


Figure 2.6. Percentage of pyruvate dehydrogenase activity in the active form in kidney and heart extracts of hibernating and euthermic S. lateralis. No active a activity was detected in kidney extracts from hibernating animals. Superscript a represents significant difference from control at the $P<0.005$ level. Inset: total PDH activity $(\underline{a}+\underline{b})$ in units of U/gram wet weight in the same extracts. All results represent the mean of 3-5 tissue; error bars represent SEM. 


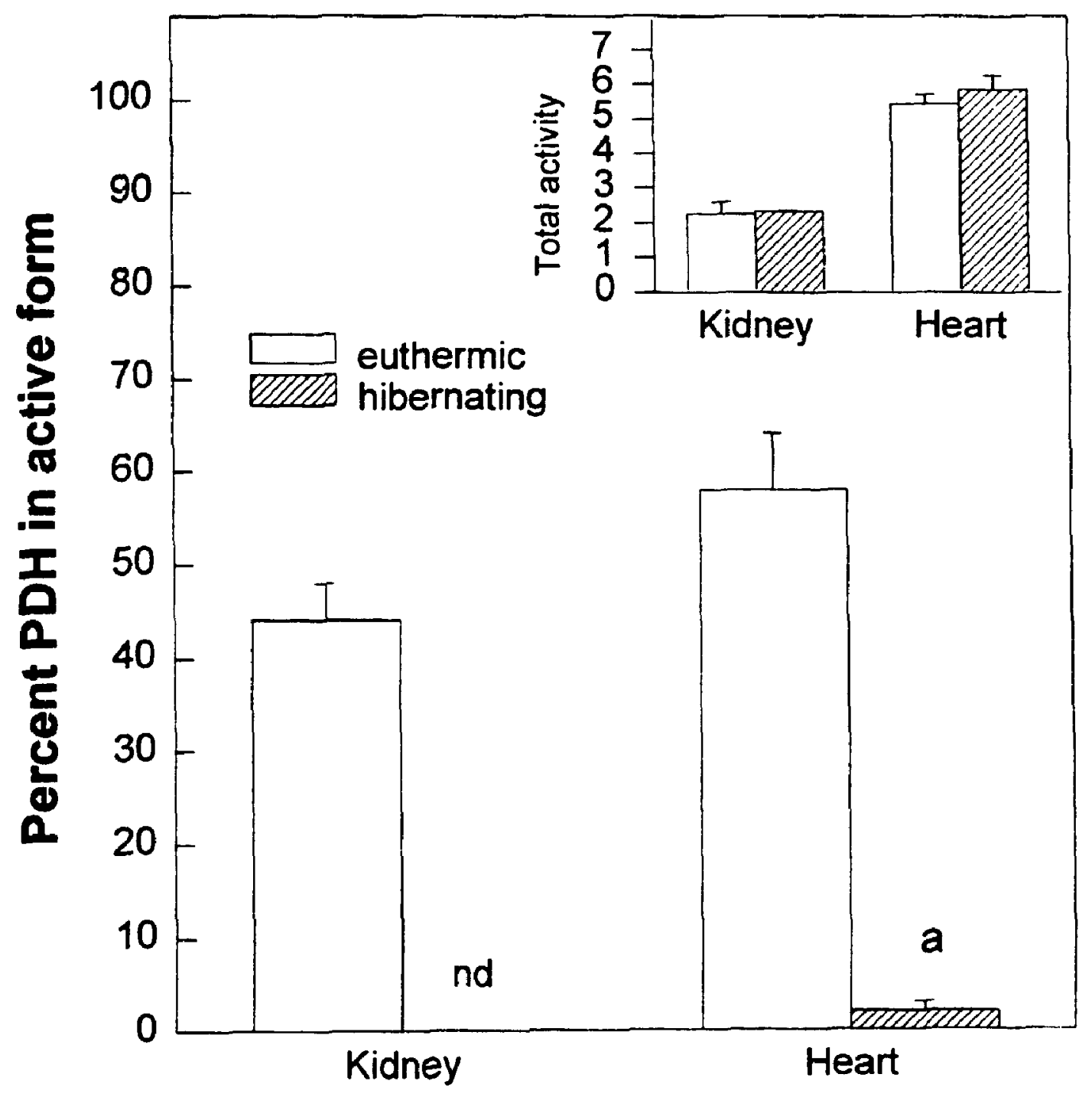


Chapter 3

Temperature effect on kinetic and thermodynamic parameters of liver B-hydroxybutyrate dehydrogenase during hibernation 


\section{Introduction}

It is well known that hibernation is a state of metabolic suppression, used by some mammals as an energy sparing strategy for winter survival in temperate climes. These animals 'fatten up' prior tc entry into torpor and lipids provide the primary source of fuel during torpor (Dark and Ruby 1993). During hibernation, protein and glucose utilization is inhibited (Tashima et al 1970 ) by a coordinated shut down of glycolysis and protein degradation relative to an accelerated mobilization of triglyceride reserves. These are largely oxidized, but some portion is used to synthesize ketone bodies, predominantly at the liver, were they are circulated throughout the body as a source of metabolic fuel for other organs (Krilowicz 1985). The presence of ketone bodies in the blood has been shown to inhibit glucose uptake in many tissues during starvation relative to the increased oxidation of fatty acids in many tissues (RoL:inson and Williamson 1980). Furthermore, ketone bodies, themselves a product of hepatic $B$-oxidation, can be metabolised by many tissues (Robinson and Williamson 1980). During hibernation, levels of ketone bodies have been shown to increase (Krilowicz 1985), likely a result of increased acetyl-CoA availability resulting from a suppression of carbon entry into the TCA cycle (Chapter 2, present study).

B-hydroxybutyrate dehydrogenase (BDH; E.C. 1.1.1.30) is the enzyme responsible for the interconversion of the ketone bodies, acetoacetate (AA) and $B$-hydroxybutyrate $(\mathrm{BOHB}): \mathrm{B}$-hydroxybutyrate $+\mathrm{NAD}^{+}+\mathrm{H}_{2} \mathrm{O} \longleftrightarrow$ acetoacetate $+\mathrm{NADH}+\mathrm{H}^{+}($Barman 1969). Both $\mathrm{AA}$ and $\mathrm{BOHB}$ are readily mobilized, however, BOHB is the prominent form of ketone exported from the liver (Krilowicz 1985). Although the reason why is unclear, this is likely a 
compensatory mechanism to stabilize the $\mathrm{NADH}$ : $\mathrm{NAD}^{+}$ratio of liver cells. As well, the presence of the reduced form helps to prevent acidification associated with buildup of the oxidized form as is also the case with lactate (reduced form of pyruvate) and malate (reduced form of oxaloacetate). BDH is located in the inner mitochondrial membrane and is a lipid dependent enzyme with an absolute requirement of phosphatidyl choline for function (Fleischer et al. 1983). Most studies of this enzyme have focused on lipidenzyme interactions, as BDH is strongly modulated by phospholipid composition, however, there is a deficit of literature concerning the role of this enzyme during hibernation and the corresponding effects of temperature on the modulation of activity.

It is the purpose of the present study to compare the effects of temperature on the modulation of BDH activity in C. Iudivicianus, S. lateralis, and rats. Whereas rats are homeotherms and must actively defend a constant high body temperature, the golden-mantled ground squirrel (Spermophilus lateralis) and the black-tailed prairie dogs (Cynomys ludivicianus) are two species of varying hibernation 'ability'. During periods of torpor, S. lateralis has been shown to reduce its body temperature to $5^{\circ} \mathrm{C}$ (Twente and Twente 1965) while C. Iudivicianus can lower its body temperature daily to $13^{\circ} \mathrm{C}$ (Harlow and Menkins 1975). Using temperature as a probe, the determination of liver $\mathrm{Km}$ values, maximal activities, and $\mathrm{pH}$ behavior of hepatic $B D H$ in these animals will provide a means of evaluating the effects of temperature and hibernation on the modulation of BDH activity. 


\section{Materials and Methods}

Animals and Chemicals. The acquisition procedure 'or Spermophilus lateralis tissues is outlined in Chapter 2. Five male and 5 female black-tailed prairie dogs (Cynomys ludivicianus) were captured in Southeastern Wyoming during July 1993 and housed in standard rat cages at the University of Wyoming on a natural (fall) photoperiod at $22^{\circ} \mathrm{C}$. Animals were fed Purina 5001 rodent diet. After 38 days, 6 of the 10 animals that were captured were sacrificed. The remaining 4 prairie dogs continued to iatten for an additional 36 days, at which point they were placed in their cages without food (but with water) at $5^{\circ} \mathrm{C}$. After 6 weeks of hibernation, the four animals were sacrificed. Ratus ratus were obtained from the animal care facility at Carleton University. At sacrifice, animals were rapidly dissected and tissue samples were frozen in liquid nitrogen and then stored at $-80^{\circ} \mathrm{C}$.

Preparation of Samples. Frozen liver samples were homogenized (approx. $1: 4 \mathrm{w:v}$ ) in ice-cold $50 \mathrm{mM}$ phosphate buffer ( $\mathrm{pH} 8.5$ ), containing $15 \mathrm{mM}$ B-mercaptoethanol (vith a few crystals of phenylmethylsulfonylfluoride added) for 2 bursts of $15 \mathrm{sec}$ with a Janke and Kunkel Ultraturex homogenizer at $70 \%$ full speed. Samples were then centrifuged for 20 minutes at $30,000 \times \mathrm{g}$ at $4^{\circ} \mathrm{C}$ in a Sorvall RC-5B refrigerated superspeed centrifuge. The supernatant fraction was subsequently passed through a small column ( $1 \mathrm{~cm} \mathrm{X} 4 \mathrm{~cm}$ ) of Sephadex G-25 by centrifugation on a benchtop centrifuge to remove low molecular weight species (Helmerhorst and Stokes 1980) and stored on ice prior to use. 
Assay of enzymatic activity. Assays of enzymatic activity were carried out in both directions : $A A+N A D H$ (direction $A$ ) and $B O H B+N A D^{+}$(direction $B$ ). For direction $\mathrm{A}$, the $\mathrm{pH}$ of all buffers was set to $\mathrm{pH} 7.5$, while in direction $\mathrm{B}$, all buffers were set to $\mathrm{pH}$ 8.5. BDH activity was monitored by following either $\mathrm{NADH}$ oxidation or $\mathrm{NAD}^{+}$reduction at $340 \mathrm{~nm}$ using a Gilford 250 spectrophotometer with an attached refrigerated water bath for temperature control of cuvettes. One unit of activity is defined as the amount of enzyme required to oxidize $1.0 \mu$ mole $B O H B$ per minute. Optimal concentrations of substrates were as follows : $20 \mathrm{mM}$ BOHB, $0.4 \mathrm{mM} \mathrm{NAD}^{+}, 0.6 \mathrm{mM} \mathrm{AA}$, and $0.15 \mathrm{mM}$ NADH. The presence of non-specific utilization of NADH in the direction of AA reduction was effectively quenched with the addition of $1 \mu$ l of rotenone saturated ethanol for each $1 \mathrm{ml}$ of assay mixture. The $\mathrm{pH}$ values of all buffers were set to the appropriate $\mathrm{pH}$ at room temperature and were allowed to fluctuate with changing temperature. (for phosphate this corresponds to a $0.003 \mathrm{pH}$ unit decrease per $1^{\circ} \mathrm{C}$ increase and a $0.028 \mathrm{pH}$ unit decrease per $1^{\circ} \mathrm{C}$ increase for tris; Dawson et al 1987).

Arrhenius Plots. Arrhenius plots were constructed from maximal activity determinations for the direction of $\mathrm{BOHB}$ oxidation (as described above) for temperatures ranging from $45^{\circ} \mathrm{C}$ to $5^{\circ} \mathrm{C}$ in both phosphate and tris buffers.

Quentification of BOHB. Acid extracts of tissues were prepared by homogenizing frozen samples in $6 \%$ perchloric acid containing $1 \mathrm{mM}$ EDTA (1:5 (w/v), approximately $100 \mathrm{mg}$ per preparation) with a Diamed Pro 200 homogenizer set to full power followed by centrifugation in a Heraeus Biofuge 15 at $20000 \times \mathrm{g}$ for 25 minutes. The supernatant fraction was collected and neutralized with $300 \mathrm{mM}$ tris buffer containing $3 \mathrm{~N} \mathrm{KOH}, 400 \mathrm{mM} \mathrm{KCl}$ and 
centrifuged again (as above). Acid extracts were stored at $-80^{\circ} \mathrm{C}$ prior to assay. BOHB tissue concentrations were determined by kit (Sigma Cat. \# 310-A) which involved the enzymatic determination of $B O H B$ concentration from the change in absorbance at $340 \mathrm{~nm}$ in a Dynatech MR-5000 microplate reader in a final well volume of $270 \mu$.

Calculations. $\mathrm{Km}$ values were determined by fitting the data to the Hill equation through a nonlinear least-squares regression program (Brooks 1992). Statistical analyses were performed by two-tailed Students t-test with $P<0.05$ as the lower limit for significant differences among results. 


\section{Results}

Concentrations of the ketone body $\mathrm{BOHB}$ were determined in tissues of two hibernating species, C. Iudivicianus and S.lateralis and a nonhibernating species, the rat (Table 3.1). In the rat, $\mathrm{BOHB}$ was undetectable in 3 out of the four tissues and displayed an extremely low value in heart extracts. However, in the hibernating species, there was a dramatic increase of this metabolite in all of the hibernating tissues tested. In S. lateralis, levels of BOHB rose by $30 \%$ in Inver, 8 -fold in muscle, 3-fold in heart, 11-fold in BAT of hibernators versus euthermic controls. Furthermore, BOHB was only detected in hibernating WAT extracts from hibernators and was not found in control extracts. In C. ludivicianus, levels of BOHB rose by 15 -fold in liver and 3-fold in muscle of hibernators compared with controls, and BOHB was only detected in hibernating tissue extracts of heart and BAT. No BOHB was detected in C. Iudivicianus WAT extracts. Furthermore, levels of the ketone in euthermic animals were in many cases significantly greater than in the corresponding rat tissue.

Maximal activities for liver B-hydroxybutyrate dehydrogenase (BDH) in the three species in the direction of BOHB oxidation are shown in Table 3.2. Activities were similar in rat and $S$. lateralis at $22^{\circ} \mathrm{C}$ but were lower for $\mathrm{C}$. Iudivicianus. When assayed at $5^{\circ} \mathrm{C}$, the activity of $\mathrm{BDH}$ was reduced 6-fold in liver extracts from rat and C. ludivicianus, and about 10 fold in both hibernating and euthermic extracts from $S$. lateralis liver. There were no significant differences in BDH activities in S. lateralis liver extracts from euthermic versus hibernating animals indicating that the entrance into torpor does not alter enzyme activity. 
$\mathrm{Km}$ values for the liver enzyme from the three species were quantified at both $22^{\circ} \mathrm{C}$ and $5^{\circ} \mathrm{C}$ to determine the effect of lowered temperature on liver BDH Km values. These are shown in Table 3.3. $\mathrm{Km}$ values for acetoacetate were reduced in all species at $5^{\circ} \mathrm{C}$, to $40 \%$ in rat and $\mathrm{C}$. Iudivicianus liver and $70 \%$ in S. lateralis liver of the values determined at $22^{\circ} \mathrm{C}$. The same was true for the cosubstrate, $\mathrm{NADH}$, where $\mathrm{Km}$ values decreased at $5^{\circ} \mathrm{C}$ for both the rat and S. lateralis enzyme. In the opposite direction, $\mathrm{Km}$ values for $\mathrm{NAD}^{+}$ were unaffected by assay temperature. Substrate $\mathrm{Km}$ values were also determined for $B O H B$ at a range of temperatures, shown in Figure 3.1. Temperature had no effect on the $\mathrm{Km}$ values of the enzyme from either $S$. lateralis or $C$. Iudivicianus liver and the $\mathrm{Kn}$ value for $\mathrm{BOHB}$ was the same for both hibernating and euthermic animals at all temperatures. However, $\mathrm{Km}$ values for $\mathrm{BOHB}$ increased 5 -fold at $5^{\circ} \mathrm{C}$ for rat $\mathrm{BDH}$ relative to those determined at temperatures greater that $17^{\circ} \mathrm{C}$.

$\mathrm{pH}$ optima for $\mathrm{BDH}$ from all three species were determined to assess the possible role of hypercapnia induced acidosis during hibernation on the modulation of enzyme activity (Malan et al 1973). The pH behavior of BDH from all three species showed a broad optimum in the direction of $A A$ reduction in the $\mathrm{pH}$ range of $6.5-7.2$ whereas a sharper optimum at approximately $\mathrm{pH} 8.2$ was seen in the reverse direction. In all of the tissues tested, the $\mathrm{pH}$ optimum did not change at the two assay temperat'ures in the directions of $B O H B$ oxidation or $A A$ oxidation $(n=3)$.

Arrhenius plots for liver $B D H$ from all three species (plots not shown) were used to calculate activation energies shown in Table 4. All plots were 
linear over the temperature range tested, demonstrating the absence of temperature induced conformational transitions with temperature. Activation energies for $\mathrm{BDH}$ were determined in tris and phosphate buffer and were slightly but not significantly higher for all species when performed in phosphate buffer. 


\section{Discussion}

During hibernation, the increase in fatty acid oxidation promotes ketosis in hibernating mammals as demonstrated by the accumulation of BOHB, foremost in the liver where it is synthesizec and as well to a lesser degree in otner tissues such as the heart. kidney. brown adipose (BAT). white adıpose (WAT) and muscle where it is consumed. This is clear from Table 3.1 where the levels of BOHE :ose in all $C$. Iudiivicianus and $S$. lateralis tissues during hibernation. Ketosis has previously been documented with measurements of $B O ! 1 B$ in the blood of Spermophilus beldingi during hibernatıon (Krilowicz 1985). Furthermore. levels of BOHB from Euthermic tissues were generally higher thän those in the nonhibernating rat indicating a proportionately greater use of fatty acids by the 2 hibernating species. As a result. the functional integrity of $B \mathrm{DH}$. which plays a prominent role in this process, must be maintained over the range of temperatures experienced by hibernating species reiative to rats which maintain a relatively consiant high body temperature

Maximal actıvities of liver BDH from the three species were similar in rat and $S$. lateralis at $22 C$ whereas $C$ ludivicianıs. a larger mammal had lower activity. At $5^{\circ} \mathrm{C}, \mathrm{BDH}$ activity was suppressed in all animals, corresponding to $Q_{10}$ values of $2.5,2.3$, and 3 calculated from enzyme activities measu. ed at $22^{\prime \prime} C$ and $5^{\circ} \mathrm{C}$ for liver $\mathrm{BDH}$ from rat, $C$. Iudivicianus and $S$. lateralis. As well, identical activities in between hibernating and euthermic liver extracts indicated that the entrance into torpor did not alter enzyme activity. 
Hypercapnia induced acidosis is a mechanism that has received attention In the literature as a potential modulator of enzyme activity in hibernating species (Malan et al. 1985). A relative acid shift of the cytoplasm during hibernation could Influence the act vities of enzymes and pathways that are $\mathrm{pH}$ sensitive. $\mathrm{pH}$ optima were determined for liver $\mathrm{BDH}$ from the three species and were typical of dehydrogenases, with broad $\mathrm{pH}$ optıma in the direction of $\mathrm{AA}$ reduction in the range of $6.5-7.2$, while the oxidation reaction had a pH optima of 8.2 for the hibernator enzymes and abou: 8.1 for the rat enzyme. Literature values for $B D H$ optima are Identical in the direction of $\mathrm{BOHB}$ oxidation (Gotterer 1967). When tested at 5 C the $\mathrm{pH}$ optima were identical which suggests that temperature does not alter the $\mathrm{pH}$ behavior of liver $\mathrm{BDH}$ from the three species

Energies of activation were determıned from Arrhenius plots performed in tris and phosphate buffers. This experiment was specifically designed to elucidate the contribution of acidotic inhibition arising from an acid shift of intracellular $\mathrm{pH}$ during hibernation arising from temperature induced pKa changes on histidine residues (contained in peptides and proteins). This has previously been implicated to account for inhibition of enzyme a-tivity beyond that predicted by temperature effects alone (1e. Q10; Malan et al. 1973, 1985; Chapter 1, present study). The pH of all buffers is altered by temperature change. The major portion of intracellular buffering is provided by histidine whose alpha-imidazole groups pKa changes with temperature in a manner that results in a $0.018 \mathrm{pH}$ unit increase for every $1^{\circ} \mathrm{C}$ decrease in temperature. This $p K a$ change mimics the efiect of temperature on the pKa of water, and the net result of buffering by $\alpha$-imidazolium groups is that a constant charge state is preserved on proteins despite changing temperature. 
This alphastat regulation allows protein conformation and enzyme kinetic properties to be largely conserved for most proteins as temperature varies within the physiological range. Many mammalian enzymes generally function well within a narrow high temperature range that reflects the homeothermic environment of the cells and it has been proposed that two of the means of metabolic suppression that could be important in hibernation are 1) low temperature effects on enzymes (discussed in Chapters 1 and 4, present study); and 2) differential pH effects on enzymes at low temperatures since the respiratory acidosis that develops in hibernation means that the intracellular $\mathrm{pH}$ of the hibernating cell is somewhat lower than would be expected from the calculated $\mathrm{pH}$ increase that would occur due to alphastat regulation (Malan 1973, 1985). Hence, for sensitive enzymes, this relative acidosis could change enzyme function at the hibernating body temperature. To test this hypothesis, BDH was assayed in 2 different buffers; phosphate which shows a small pH change with temperature $(0.002 \mathrm{pH}$ unit increase for $1^{\circ} \mathrm{C}$ decrease) and therefore provides a relative acidosis (compared with intracollular histidine buffering) for enzymes assayed at low temperatures; and tris $\left(0.028 \mathrm{pH}\right.$ unit increase for $1^{\circ} \mathrm{C}$ deciease) which gives the opposite effect - a pH shift that is more basic than expected intracellular!y. Any different behavior of BDH in these two buffers at low temperature would indicate, therefore, that enzyme function in vivo is influenced by the relative acidosis of the intracellular environment in tissıes during hibernation. In all species, activation enırgies determined in phosphate buffer were slightly higher but not signiiicantly different than those determined in tris buffer. This indicates that liver $3 \mathrm{DH}$ from the 3 species is not modulated by temperature effects on intracellular $\mathrm{pH}$ and the reduction in activity is strictly a function of temperature. Furthermore, no breaks were observed in any Arrhenius plcts 
of $\mathrm{BDH}$, demonstrating the absence of conformacional changes induced by temperature.

$\mathrm{Km}$ values for liver $B D H$ indicated increased $\mathrm{Km}$ values for $A A$ in the three species with lowered temperature. This may be a factor for the . ole of $\mathrm{BOHB}$ synthesis for export from liver during hibernation. $\mathrm{Km}$ values for $\mathrm{BOHB}$ tested in the temperature range of $5^{\circ} \mathrm{C}$ to $27^{\circ} \mathrm{C}$ were unchanged for liver $\mathrm{BDH}$ from the two hibernators, whereas they decreased 5-fold for the rat enzyme at $5^{\circ} \mathrm{C}$ relative to determinations at $17^{\circ} \mathrm{C}$ and above. Since $\mathrm{Km}$ values are a measure of enzyme function, these results indicate a greater maintenance of functional integrity of the enzymes from both hibernating species over this range of temperatures relative to the enzyme from the non-hibernator.

During torpor, levels of the ketone body $\mathrm{BOHB}$ accumulate during hibernation in tissues form $S$. lateralis and $C$. ludivicianus to fuel tissues as part of a carbohydrate sparing strategy. This form of ketore body can be intercc רverted with acetoacetate by the enzyme BDH. In this study, the effects of temperature on this enzyme were determined in order to elucidate the effect of torpor on the function of this enzyme. From kinetic studies, it is clear that $B D H$ from the two hibernating species maintains functional integrity over the range of temperatures between $5^{\circ} \mathrm{C}$ and $27^{\circ} \mathrm{C}$ better that the enzyme from the non-hibernator. Furthermore, the enzymes from the two hibernating species are not modulated by acidosis or temperature effects on the pKa of intracellular buffering. The suppression of activity during bouts of torpor is solely a function of temperature reduction in activity, with corresponding $Q_{10}$ values of $2.6,2.3$ and 3 for the enzyme from rat, $C$. ludivicianus and $S$. lateralis. 
Table 3.1. Concentrations of BOHB in tissues of rat, $C$. Iudivicianus and $S$. lateralis expressed in $\mu$ moles/gram wet weight determined in PCA extracts of liver, skeletal muscle, heart, white adipose tissue (WAT) and brown adipose tissue (BAT) from the thiree species. All values are presented as means \pm SEM and are the product of 3-4 separate determinations. All values determined in hibernating extracts are significantly higher than those determined in corresponding euthermic extracts $(P<0.005)$ except in WAT extracts which did not change during hibernation.

\begin{tabular}{|c|c|c|c|}
\hline Animal & Tissue & hibernating & euthermic \\
\hline \multirow[t]{4}{*}{ Rat } & Liver & - & $0.00 \pm 0.00$ \\
\hline & Muscle & -. & $0.00 \pm 0.00$ \\
\hline & Heart & - & $0.01 \pm 0.00$ \\
\hline & WAT & - & $0.00 \pm 0.00$ \\
\hline \multirow[t]{5}{*}{ C. luaivicianus } & Liver & $0.30 \pm 0.05$ & $0.02 \pm 0.01$ \\
\hline & Muscle & $0.03 \pm 0.01$ & $0.01 \pm 0.00$ \\
\hline & Heart & $0.03 \pm 0.01$ & $0.00 \pm 0.00$ \\
\hline & WAT & $0.00 \pm 0.00$ & $0.00 \pm 0.00$ \\
\hline & BAT & $0.10 \pm 0.01$ & $0.00 \pm 0.00$ \\
\hline \multirow[t]{5}{*}{ S. lateralis } & Liver & $0.40 \pm 0.01$ & $0.28 \pm 0.03$ \\
\hline & Muscle & $0.15 \pm 0.04$ & $0.02 \pm 0.01$ \\
\hline & Heart & $0.13 \pm 0.05$ & $0.05 \pm 0.01$ \\
\hline & WAT & $0.01 \pm 0.01$ & $0.00 \pm 0.00$ \\
\hline & BAT & $0.45 \pm 0.07$ & $0.04 \pm 0.01$ \\
\hline
\end{tabular}


Table 3.2. Activities of BDH (mU/gm wet $\mathrm{wt}$ ) in rat liver, $S$.

lateralis liver and C. Iudivicianus liver at $22^{\circ} \mathrm{C}$ and at $5^{\circ} \mathrm{C}$ in the direction of BOHB oxidation. Assays were performed under optimal conditions as previously described. All values are presented as mean \pm SEM (n). There was no significant difference in activity between BDH from hibernating versus euthermic S. lateralis and C. Iudivicianus tissue and hence values were combined. All activities were significantly lower when performed at $5^{\circ} \mathrm{C}$ relative to $22^{\circ} \mathrm{C}$. $Q_{10}$ values calculated for the reduction in activity at $5^{\circ}$ relative to $22^{\circ} \mathrm{C}$ are $2.5,2.3,3.0$ for S. lateralis, C. ludivicianus, and rat, respectively.

\begin{tabular}{|l|c|c|}
\hline Tissue & $\begin{array}{c}\text { Temp. } \\
\left({ }^{\circ} \mathrm{C}\right)\end{array}$ & $\begin{array}{c}\text { Activity } \\
\text { (mU/gm wet wt) }\end{array}$ \\
\hline & & \\
\hline Rat liver & $22^{\circ} \mathrm{C}$ & $158.3 \pm 13.1(4)$ \\
\hline & $5^{\circ} \mathrm{C}$ & $25.0 \pm 2.06(4)$ \\
\hline C. ludivicianus liver & $22^{\circ} \mathrm{C}$ & $84.0 \pm 6.6(6)$ \\
\hline & $5^{\circ} \mathrm{C}$ & $15.0 \pm 2.2(6)$ \\
\hline & & \\
\hline S. lateralis liver & $22^{\circ} \mathrm{C}$ & $144.4 \pm 18.4(10)$ \\
\hline & $5^{\circ} \mathrm{C}$ & $14.6 \pm 1.87(5)$ \\
\hline
\end{tabular}


Table 3.3. $\mathrm{Km}$ values for $\mathrm{BDH}$ at $5^{\circ} \mathrm{C}$ and $22^{\circ} \mathrm{C}$. All assays were conducted in phosphate buffer set to $\mathrm{pH} 7.5$ at $22^{\circ} \mathrm{C}$. Values are presented as mean \pm SEM and are the product of 3-5 separate determinations for rat $B D H$ and 810 separate determinations from the enzyme from both hibernators. There were no significant differences in $\mathrm{Km}$ values between the enzyme from hibernating and euthermic liver and hence the results were combined. Superscript $a$ and $b$ refer to significant differences between the two temperatures at the $P<0.005$ and $P<0.05$ levels, respectively.

\begin{tabular}{|l|c|c|c|c|}
\hline Tissue & $\begin{array}{c}\text { Temp. } \\
\left({ }^{\circ} \mathrm{C}\right)\end{array}$ & $\begin{array}{c}\text { NAD } \\
(\mu \mathrm{M})\end{array}$ & $\begin{array}{c}\text { AA } \\
(\mu \mathrm{M})\end{array}$ & $\begin{array}{c}\text { NADH } \\
(\mu \mathrm{M})\end{array}$ \\
\hline \multirow{2}{*}{ Rat liver } & $22^{\circ} \mathrm{C}$ & $79 \pm 3$ & $96 \pm 9$ & $17 \pm 3$ \\
\cline { 2 - 5 } & $5^{\circ} \mathrm{C}$ & $70 \pm 8$ & $40 \pm 3^{\mathrm{a}}$ & $6.0 \pm 2^{\mathrm{b}}$ \\
\hline \multirow{2}{*}{ S. lateralis liver } & $22^{\circ} \mathrm{C}$ & $59 \pm 10$ & $64 \pm 5$ & $18 \pm 0.4$ \\
\cline { 2 - 6 } & $5^{\circ} \mathrm{C}$ & $77 \pm 5$ & $46 \pm 4^{\mathrm{b}}$ & $9.0 \pm 2^{\mathrm{b}}$ \\
\hline \multirow{2}{*}{ C. Iudivicianus liver } & $22^{\circ} \mathrm{C}$ & $103 \pm 10$ & $82 \pm 8$ & $10 \pm 0.7$ \\
\cline { 2 - 6 } & $5^{\circ} \mathrm{C}$ & $78 \pm 11$ & $31 \pm 4^{\mathrm{a}}$ & $8.0 \pm 0.9$ \\
\hline
\end{tabular}


Table 3.4. Activation energies (calculated from Arrhenius plots) for liver BDH from three species. Assays were performed in tris and phosphate buffers over the range of temperatures from $40^{\circ} \mathrm{C}$ to $4^{\circ} \mathrm{C}$ proceeding in the direction of $\mathrm{BOHB}$ oxidation. The $\mathrm{pH}$ of both buffers was set to $\mathrm{pH} 8.5$ at $22^{\circ} \mathrm{C}$ and allowed to fluctuate with temperature. All numbers are presented as means \pm SEM ( $n)$. There were no significant differences in activation energy between values determined in tris or phosphate buffers. As well, there was no significant difference between hibernating and euthermic tissues. Superscript a denotes significant differences at the $P<0.005$ level from the corresponding rat liver value in the same buffer.

\begin{tabular}{|l|c|c|}
\hline Tissue & $\begin{array}{c}\text { Ea (kcal/mol) } \\
\text { in tris buffer }\end{array}$ & $\begin{array}{c}\text { Ea (kcal/mol) } \\
\text { in phosphate buffer }\end{array}$ \\
\hline \hline Rat liver & & \\
\hline & $9.64 \pm 0.65(6)$ & $10.11 \pm 0.07(6)$ \\
\hline C. ludivicianus liver & & \\
\hline & $7.46 \pm 0.43(3)^{\mathrm{a}}$ & $8.68 \pm 0.37(3)^{\mathrm{a}}$ \\
\hline S. lateralis liver & & \\
\hline
\end{tabular}


Figure 3.1. Effect of temperature on $\mathrm{Km}$ values for $\mathrm{BOHB}$ for $\mathrm{BDH}$ from $\mathrm{C}$. Iudivicianus, S. lateralis and rat liver. All data points are the mean of 4 preparations for rat values and 8 preparations for hibernator values; error bars denote SEM. There were no significant differences in $\mathrm{Km}$ values between temperatures for $C$. ludivicianus and $S$. lateralis, whereas for the rat enzyme, significant differences from the corresponding value at $27^{\circ} \mathrm{C}$ $(P<0.005)$ are shown with an appended a. 
Chapter 4

A comparison of functional and structural properties of glycerol-3-phosphate dehydrogenase from $C$. Iudivicianus and rabbit. 


\section{Introduction}

Many mammalian species have evolved the ability to lower their body temperature to limit the expenditure of energy in temperate climes. The blacktailed prairie dog (Cynomys ludivicianus) is a daily heterotherm that can lower its body temperature to $13^{\circ} \mathrm{C}$ during winter nights (Harlow and Menkens 1985). Typical of all hibernating mamrnals, the mobilization of triglycerides during bouts of torpor increases relative to the catabolism of carbohydrate and protein stores. The three forms of metabolic substrate derived from the catabolism of triglycerides are i) fatty acids which undergo B-oxidation to yield the majority of the energy; ii) ketone bodies produced from acetyl $\operatorname{CoA}$; and iii) glycerol-3-phosphate and free glycerol derived from the breakdown of triacylglycerides and phosphoglycerides (Dark and Ruby 1993). Glycerol-3phosphate dehydrogenase is responsible for the metabolism of glycerol-3phosphate (G3P). Free glycerol is converted to glycerol-3-phosphate (G3P) by the action of glycerol kinase. G3P can then be converted to dihydroxyacetone phosphate (DHAP) by the action of glycerol-3-phosphate dehydrogenase (G3PDH) and can enter into glycolysis at the triose phosphate level (Lehninger 1975). Alternatively, G3P can participate in the glycerol phosphate shuttle for direct transfer of cytosolic reducing equivalents to the electron transport chain via mitochondrial glycerol-3-phosphate oxidase (flavin linked). During torpor, there is a surplus of G3P derived from the catabolism of triglycerides which can participate in both the glycerolphosphate shuttle and glycolysis. Although glycolytic flux is inhibited during hibernation (Storey 1987), the arousing hibernator requires a source of gluconeogenic precursor, as glycogen stores dwindle during bouts of torpor (Tashima et al.1970). Candidates inciude lactate and body protein, however, 
glycerol derived from triglycerides can account for $60 \%$ of the replenishment of glycogen stores (Galster and Morrison 1975). As a result, there is a requirement for metabolic control at the locus of G3P metabolism in hibernating species.

Hibernation represents a major thermoregulatory adaptation in some species. Conirol over the lowering of metabolic rate has focused on passive metabolic control during the entrance into hibernation as a function of reduced body temperature (Snapp and Heller 1981) or acidotic inhibition resulting from hypercapnia during torpor (Malan 1973). More recent research has focused on the modulation of metabolic flux by more active forms of enzyme control. These include: post translational.modification of key regulatory enzymes (Storey 1987a and1987b); changes in the concentrations of regulatory enzymes; reversible aggregation of enzymes (Srivastava and Bernhard 1986; Srere and Ovadi 1990) or their binding to subcellular structures (Arnold and Pette 1970); changes in concentrations of enzyme inhibitors and activators. These mechanisms however, are not apparently factors that affect G3PDH. Temperature effects are prominent modulators of enzyme activity and are ubiquitous to all enzymes during bouts of torpor. The present study will determine temperature induced changes of G3PDH activity during hibernation by comparison of functional and structural adaptations of this enzyme in hibernating species. This will be accomplished by the determination of temperature effects on enzyme activity, $\mathrm{pH}$ behavior, $\mathrm{Km}$ value, temperature induced conformational changes and stability differences. 


\section{Materials and Methods}

The acquisition procedure for $C$. ludivicianus tissue is outlined in Chapter 3. Rabbits tissues were a kind gift from Mr. E. Fudd. All animals were sacrificed by decapitation. Excised tissues were immediately immersed in liquid nitrogen and subsequently $\mathrm{s}^{+}$ored at $-70^{\circ} \mathrm{C}$. All chemicals used in this study were obtained from Sigma Cinemical Co. (St. Louis, Mo, U.S.A.) or from Boehringer Mannheim (Montreal, P.Q., Canada) and were of the highest purity available. Purified rabbit muscle $\alpha$-glycero-3-phosphate dehydrogenase (G3PDH) was obtained from Sigma Chemical Co. (St. Louis, Mo, U.S.A.).

C. Iudivicianus tissues (liver and muscle) were homogenized (1:3 w/v, approximately $1 \mathrm{gm}$ per preparation) in ice-cold $50 \mathrm{mM}$ phosphate buffer, $\mathrm{pH}$ 8.5, containing $15 \mathrm{mM}$ B-mercaptoethanol, $1 \mathrm{mM}$ EDTA (disodium salt) and $10 \%$ v/v glycerol using a Janke and Kunkel Ultraturax homogenizer at $70 \%$ full power. The supernatant was then centrifuged for 20 minutes at $27,000 \mathrm{~g}$ and desalted by centrifugation through a small G-25 Sephadex column ( $1 \mathrm{x}$ $5 \mathrm{~cm}$, approximately $0.5 \mathrm{ml}$ supernatant/culumn) pre-equilibrated in $10 \mathrm{mM}$ potassium phosphate buffer, pH 8.0 (buffer A). The supernatant was then placed on a DE-52 Sephadex column equilibrated in the same buffer, and washed with buffer $A$ until the absorbance at $2 \varepsilon ? \mathrm{~nm}$ was zero. The enzyme was eluted using a 0 to $1 \mathrm{M} \mathrm{KCl}$ gradient in buffer $A$. Active fractions were pooled and concentrated to $1 \mathrm{ml}$ using dialysis tubing (exclusion 12,000 14,000) and polyethylene glycol (mol. wt. 8000). The concentrate was then injected onto a Varian TSK 4000 size exclusion column $(7.5 \mathrm{~mm} \times 60 \mathrm{~cm}$; equipped with a guara column) equilibrated in $10 \mathrm{mM}$ potassium phosphate buffer ( $\mathrm{pH} \mathrm{7.0)}$ and $100 \mathrm{mM} \mathrm{KCl}$ and run $\mathrm{cn}$ an HPLC. The column was 
developed in the same buffer and active fractions were pooled and placed on a Matrix Red column equilibrated in $5 \mathrm{mM}$ phosphate buffer containing $10 \%$ (v/v) glycerol and $15 \mathrm{mM}$ B-mercaptoethanol (buffer B). The column was washed with buffer $B$ until the absorbance at $280 \mathrm{~nm}$ was zero and then the enzyme was eluted using a 0 to $1 \mathrm{M} \mathrm{KCl}$ gradient in buffer $B$ and active fractions were pooled. The final preparation was stored in buffer $B$ and was sTable 4.for at least two weeks with no loss of activity. Purity of the enzymes were confirmed by SDS-PAGE and by a single protein peak eluting on a Zorbax reverse phase column equilibrated in $0.15 \%$ TCA and eluted with a 5 $-60 \%$ acetonitrile gradient run on an HPLC. Purity of the rabbit enzyme obtained from Sigma was also confirmed as above.

Crude extracts used for activity measurements were prepared by homogenization of liver and muscle samples from both $C$. Iudivicianus and rabbit (1:3, approximately $20 \mathrm{rr}, 2$ per preparation) in ice cold $50 \mathrm{mM}$ imidazole, pH 7.5 containing 10\% (v/v) glycerol, 1 mM EDTA and $15 \mathrm{mM}$ Bmercaptoethanol. Homogenates were centrifuged as above and the supernatant stored on ice prior to assay. Enzyme activity was monitored in both directions of catalysis, by following either the reduction of $\mathrm{NAD}^{+}$or the sxidation of NADH at $340 \mathrm{~nm}$ using a Gilford 250 spectrophotometer with a water jacketed cell holder for temperature control. Standard assays were performed in $50 \mathrm{mM}$ potassium phosphate buffer at $\mathrm{pH} 7.5$ in the direction of DHAP reduction or in $50 \mathrm{mM}$ imidazole buffer, $\mathrm{pH} 8.5$, in the direction of G3P oxidation. Optimal concentrations of substrates were as follows: $0.1 \mathrm{mM}$ NADH and $0.5 \mathrm{mM}$ DHAP in the reduction direction and $10 \mathrm{mM}$ glycerol-3phosphate and $1 \mathrm{mM} \mathrm{NAD}^{+}$in the oxidation direction to a final cuvette volume of $1 \mathrm{ml}$. Assays were initiated with the addition of either G3P or DHAP 
and demonstrated the absence of non-specific activities utilizing either NAD+ or $\mathrm{NADH}$. The $\mathrm{pH}$ of all buffers was sei at $\mathrm{pH} 7.5$ at $25^{\circ} \mathrm{C}$ and was allowed to fluctuate with temperature; for phosphate buffer this results in a $0.002 \mathrm{pH}$ unit increase per $1^{\circ} \mathrm{C}$ and for imidazole, a pH unit increase of 0.017 per $1^{\circ} \mathrm{C}$ decrease in temperature (Dawson 1969). For assays to be run at $5^{\circ} \mathrm{C}, \mathrm{pH}$ was determined at $22^{\circ} \mathrm{C}$ and compensation was made for the differences in buffer $\mathrm{pKa}$ with temperature. Determination of $\mathrm{pH}$ optima was performed in phosphate buffer under optimal conditions. Km valuEs were determined by fitting the data to the Hill equation through a nonlinear least-squares regression program designed by Dr. S. P. J. Brooks (1992).

Protein concentration was determined by the Bio-Rad assay kit (Coomassie blue G-250 bindıng method; Bradford 1976) with bovine serum albumin as the standard. Spectrophotometric quantification was performed utilizing a Dyriatech MR5000 Microplate Reader to a final volume of $260 \mu$ l per microplate well.

The native molecular mass of G3PDH was determined by size exclusion HPLC. as described in the purification procedure. Purified erizyme $(0.50 \mathrm{ml})$ was injected and the eluant was collected in $1 \mathrm{ml}$ fractions, assayed in the direction of G3P oxidation and compered to elution volumes of the following standards : ferritin, 450,000; phosphofructokinase, 360,000; pyruvate kinase, 237,000; catalase, 232,000; aldolase, 160,000; hexokinase, 10: ,000; and adenylate kinase, 41,000. The subunit molecular weight was determined by SDS-PAGE run on an $8 \%$ acrylamide gel and compared io commercially available standards. Standards used were : myosin, 200,000 kDa; B-galactosidase, 116,250 kDa; phosphorylase b, 97,400; serum 
albumin, 66,200; ovalbumin, 45,000; carbonic anhydrase, 31,000; trypsin inhibitor, 21,500; lysozyme, 14,400; and aprotinin, 6,500 .

Isoelectric focusing was performed by the method of Vesterberg (1971) using an LKB Products 8101 IEF column $(110 \mathrm{ml})$ with pH 3.5 to 10 LKB ampholines ir, a sucrose density gradient with column development at $500 \mathrm{~V}$ for 16 ... Fractions were assayed in the direction of G3P oxidation.

Arrhenius plots $\left(\log V\right.$ vs $1 / K^{\circ}$ ) were constructed from measurements of enzyme activities at $9-12$ temperatures ranging from $40^{\circ} \mathrm{C}$ to $5^{\circ} \mathrm{C}$ in $50 \mathrm{mM}$ phosphate and imidazole buffers. Assays were conducted in the direction of G3P oxidation in phosprate and imidazole buffers which were set to $\mathrm{pH}$ i.5 at $25^{\circ} \mathrm{C}$ and allowed to fluctuate with char ging temperature.

Fluorescence measurements were carried out on a LS50 fluorometer with a water jacketed cell holder for temperature control. Excitation and emission naxima for G3PDH determined at $22^{\circ} \mathrm{C}$ were 280 and $340 \mathrm{~nm}$, respectively. Temperature induced conformational measurements were performed on aliquots of the purified enzyme (approximately $1 \mu \mathrm{g} / \mathrm{ml}$ in 20 $\mathrm{mM}$ potassium phosphate, $\mathrm{pH} 7.0$ ). Emission spectra (excitation at $280 \mathrm{~nm}$ ) were recorded in 5-nm wavelength increments and corrected by subtraction of the corresponding blank sample (minus enzymie).

For chemical denaturation studies, aliquots of purified enzyme $(0.5 \mu$ $\mathrm{g} / \mathrm{ml}$, in $20 \mathrm{mM}$ potassium pnosphate, $\mathrm{pH} 7.0$ ) were incubateo at different concentrations of guanidine hydrochloride for $60 \mathrm{~min}$ at $22^{\circ} \mathrm{C}$. After incubation, the fluorescence emission spectrum was determirred as above. 
Measurement of activity loss with increasing concentration of guanidine hydroc:iloride were as above.

Thermal inactivation experiments were carried out by heating enzyme solutions $(20 \mathrm{mU} / \mathrm{ml}$ in $20 \mathrm{mM}$ potassium phosphate buffer, $\mathrm{pH} 7.0)$ at various temperatures in Baxter heating blocks. Aliquots were withdrawn at $15 \mathrm{~min}$ intervals for 60 mins and assayed for G3PDH activity at $22^{\circ} \mathrm{C}$. 


\section{Results}

Glycerol-3-phosphate dehydrogenase (G3PDH) from C. Iudivicianus liver and skeletal muscle was purified to homogeneity as demonstrated by a single bands of G3PDH protein on an SDS-PAGE gel (Figure 4.1) and by single protein peaks eluting on reverse-phase HPLC. In addition, the retention time of the $C$. Iudivicianus protein peak was identical to that of commercially purified rabbit muscie G3PDH (data not shown). Skeletal muscle G3PDH was purified 176 fold to a specific activity of $282 \mathrm{mU} / \mathrm{mg}$ protein, while liver G3PDH was purified 50 fold to a specific activity of 257 $\mathrm{mU} / \mathrm{mg}$ protein. Table 4.1 illustrates the typical purification scheme for both liver (Table 4.1a) and muscle (Table 4.1b) G3PDH from euthermic $C$. Iudivicianus. The enzyme was purified in three steps; first by ion exchange on DE-52 followed by size exclusion chromatography on an HPLC and finally by ion exchange on a Matrix gel red column that exhibits specificity towards dehydrogenases. Gel filtration chromatography on an HPLC size exclusion column yielded a native molecular weight of $77 \pm 5 \mathrm{kDa}(n=3)$ for G3PDH for both prairie dog tissues as well as rabbit muscle, larger that the value of 68 kDa previously reported for rabbit muscle G3PDH (White 1971). The subunit molecular weight of the purified enzyme was determined from SDS-PAGE (Figure 4.1) and was $40 \pm 5 \mathrm{kDa}(n=2)$. This indicates that the native enzyme was a dimer. Isoelectric focusing of crude homogenates of G3PDH from C. Iudivicianus tissues demonstrated the presence of a single isoform with a corresponding pl of 6.4 for both muscle and liver. Previously reported values for rabbit kidney G3PDH were identical (White 1971). 
$\mathrm{pH}$ optima for G3PDH from both C. Iudivicianus tissues and rabbit muscle were typical of dehydrogenases, with a broad pH optima for the direction of DHAP reduction at 7.4 to 7.8 and a narrower $\mathrm{pH}$ optimum in the opposite direction in the range of 9.3 to 9.4 . There were no observable differences in pH optima for G3PDH in the three tissues or between optima determined at $22^{\circ} \mathrm{C}$ vs $5^{\circ} \mathrm{C}$ for both temperatures. As well, Arrhenius plots constructed from Vmax measurements over the range of $40^{\circ} \mathrm{C}$ to $5^{\circ} \mathrm{C}$ were linear in all cases with calculated energies of activation of $10.93 \pm 0.31$ $\mathrm{kcal} / \mathrm{mol}(\mathrm{n}=6)$ when performed in imidazole buffer or $14.74 \pm 0.37 \mathrm{kcal} / \mathrm{mol}$ $(n=6)$ when performed in phosphate buffer.

Maximal activities G3PDH in both directions of catalysis were determined in crude extracts of liver and muscle from rabbit and $C$. ludivicianus and are shown in Table 4.2. There were no significant differences between activities measured in tissues taken from hibernating vs euthermic $\mathrm{C}$. ludivicianus at $22^{\circ} \mathrm{C}$ and $5^{\circ} \mathrm{C}$ indicating that the entrance into torpor does not alter G3PDH activity. Maximal activities determined in both directions of catalysis were significantly higher in the liver extracts of $C$. Iudivicianus compared with rabbits whereas the reverse was true for muscle extracts. Included in Table 4.2 are the activity ratios between the oxidative and reductive direction of catalysis determined at both $22^{\circ} \mathrm{C}$ and at $5^{\circ} \mathrm{C}$. Activity ratios in all tissues increased approximately $60 \%$ with the decrease in temperature to $5^{\circ} \mathrm{C}$ except in rabbit liver which maintained the same activity ratio at both temperatures. This indicates that maximal activity of G3PDH from C. ludivicianus liver and muscle and rabbit muscle are modulated similarily by temperature change. 
G3PUH Km values for DHAP, NADH and $\mathrm{NAD}^{+}$were determined at $22^{\circ} \mathrm{C}$ and at $5^{\circ} \mathrm{C}$ for the purified enzyme from $\mathrm{C}$. ludivicanus liver and muscle and rabbit muscle (Table 4.3). With lowered temperature, $\mathrm{Km}$ values for DHAP increased in both C. ludivicianus tissues, but decreased in rabbit muscle. $\mathrm{Km}$ values for NADH did not change with temperature, while those for HAD+ increased for rabbit muscle and C. Iudivicianus liver G3PDH but did not change for the $C$. ludivicianus muscle enzyme. $\mathrm{Km}$ values for G3P were determined over a range of temperaiures for the purified enzyme from both: muscle tissues and are shown graphically in Figure 4.3. A comparison of G3PDH from the two species demonstrates a greater conservation of $\mathrm{Km}$ values for G3P in the hibernating species throughout the range of temperatures tested.

Temperature induced conformational changes were monitored by changes in tryptophan fluorescence intensity at $340 \mathrm{~nm}$. Fluorescence is a sensitive probe of localized protein motion and has been used extensively to monitor conformational changes induced by various structural modifiers such as temperature and chemical denaturants (Eftink 1994). The fluorescence emission intensity of muscle G3PDH from the two species is shown in Figure 4.3 for the temperature range of $5^{\circ} \mathrm{C}$ to $48^{\circ} \mathrm{C}$. With decreasing temperature, the fluorescence sigrial increased linearily in both tissues. However, the increase with temperature was significantly greater for G3PDH from C. Iudivicianus muscle relative to the rabbit muscle enzyme indicated by slopes of $-0.235\left(r^{2}=0.99\right)$ and $-0.169\left(r^{2}=0.98\right)$ respectively. This indicates a greater degree of conformationa! change with temperature in this species. 
Thermal stability of the two enzymes incubated at $37^{\circ} \mathrm{C}$ was also monitored, shown in Figure 4.4. While the enzyme from C. Iudivicianus muscle maintained activity over the course of 60 minutes, the activity of rabbit muscle G3PDH was strongly reduced within 15 mins and continued to decrease over time. However, at other temperatures tested, activities for muscle G3PDH from both species were either maintained over the course of 60 mins $\left(5\right.$ to $\left.27^{\circ} \mathrm{C}\right)$, or were both reduced to zero within $15 \mathrm{mins}\left(45^{\circ} \mathrm{C}\right.$ and above). The greater thermostability demonstrated by the hibernator enzyme was reflected by its chemical stabi.y. With increasing concentration of the denaturant guanidine hydrochloride, the enzyme from the hibernating species maintained activity moreso than the rabbit muscle enzyme (Figure 4.5 inset). Guanidine hydrochloride induced unfolding transitions were monitored by the fluorescence emission spectrum of muscle G3PDH from both species. Shown in Figure 4.5 is a plot of the wavelength of maximum emission intensity as a function of increasing guanidine hydrochloride concentration. Figure 4.5 demonstrates a greater wavelength shift in rabbit muscle G3PDH relative to the C. ludivicianus muscle enzyme. 


\section{Discussion}

This study was undertaken to elucidate functional and structural adaptations of G3PDH in hibernating species ty comparing the liver and muscle forms of the enzyme from $C$. ludivicianus, a hibernator, with the enzyme from rabbit, a non-hibernating control. In a variety of characteristics, the enzymes were virtually identical, exhibiting typical properties of mammalian G3PDH (White 1971). Arrhenius plots of G3PDH from $C$. Iudivicianus muscle and liver and rabbit muscle showed no breaks and yielded identical energies of activation for all three sources. The $\mathrm{pH}$ optima in both directions of catalysis were also the same for al! three enzymes at 5 and $22^{\circ} \mathrm{C}$.

Maximal activities of G3PDH in muscle and liver of rabbit and $C$. Iudivicianus were determined for both the oxidative and reductive direction of catalysis. From these measurements, the ratio of oxidative to reductive activity for G3PDH was compared between both species using temperature as a probe. In all tissues except rabbit liver, there was an increase in the relative activity of the reductive direction at $5^{\circ} \mathrm{C}$ compared to $22^{\circ} \mathrm{C}$. This discinguishes rabbit liver G3PDH from the other enzymes. With respect to G3PDH from C. Iudivicianus, temperature modulation of activity during torpor will result in an decreased relative activity towards DHAP formation and entry into glycolysis relative to a maintenance of the G3P pool.

Distinctions between rabbit muscle G3PDH and the enzyme from both C. Iudivicianus tissues lie in a comparison of functional and structural parameters at $22^{\circ} \mathrm{C}$ ana $5^{\circ} \mathrm{C}$. Functional parameters st'ıdied for G3PDH were 
$\mathrm{Km}$ values, which provide an indication of how efficiently the enzyme is performing catalysis. This is a product of active site integrity and provides a means of comparing temperature effects between G3PDH from rabbit and $C$. Iudivicianus muscle. C. Iudivicianus liver and muscle G3PDH exhibited increased or equivalent $\mathrm{Km}$ values for DHAP and $\mathrm{NAD}^{+}$at $5^{\circ} \mathrm{C}$ relative to $22^{\circ} \mathrm{C}$ while $\mathrm{Km}$ values for both substrates were decreased in the rabbit muscle enzyme at $5^{\circ} \mathrm{C}$. This implies functional differences between these three enzymes. Furthermore, $\mathrm{Km}$ values for G3P as a function of decreasing temperature over the range of 50 to $20^{\circ} \mathrm{C}$ increased 6 -fold for the enzyme from rabbit muscle, while they increased 4-fold for the enzyme from C. Iudivicianus muscle. These kinetic differences at a range of temperatures indicate that functional integrity of muscle G3PDH is better maintained in $C$. ludivicianus relative to rabbit.

Structure-function studies using temperature and chemical cienaturants also indicate differences between muscle G3PDH from both species. Both of these agents induced conformational change within the enzyme which were monitored by decreases in activity or by changes in the fluorescence emission spectra. The latter has received application in monitoring conformational and unfolding transitions by changes in emission intensity and wavelength, respectively (Eftink 1994; Sacchetta et al. 1993).

Temperature induced conformational changes were monitored by fluorescence intensity changes over the temperature range of $5^{\circ} \mathrm{C}$ to $48^{\circ} \mathrm{C}$ and showed a greater degree of change for muscle G3PDH from $C$. ludivicianus relative to rabbit. This is an indicator of a structurally less rigid enzyme from $C$. ludivicianus relative to the rabbit enzyme. Furthermore, a 
comparison with $\mathrm{Km}$ values at this same range of temperatures indicates that the maintenance of functional integrity is independent of temperature induced conformational changes.

Enzyme stability is another means of characterisation which is an indicator of the structural integrity of an enzyme. Probes of enzyme stability include temperature and denaturants such as guanidine hydrochloride both of which can be monitored by activity measurements. Furthermore, chemically induced unfolding transitions can be monitored by the effect on the fluorescence emission spectrum which can be used to distinguish between enzymes on a structural basis (Sacchetta et al. 1993). Shown in Figure 4.5 are the effects of increasing guanidine hydrochloride on activity and the fluorescence spectrum of G3PDH. Unfolding patterns for the two muscle enzymes indictate a greater overall degree of unfolding shown by the greater wavelength shift experienced for G3PDH from rabbit relative to $C$. ludivicianus This indicates structurally distinct erizymes. Furthermore, the maximal activity of muscle G3PDH from the hibernator was less sensitive to increasing guanidine hydrochloride concentration relative to the rabbit enzyme indicating a greater preservation of structural integrity of G3PDH from this species.

Thermostability of G3PDH is another parameter which serves to distinguish between muscle G3PDH from $C$. ludivicianus and rabbit muscle. Data in Figure 4.4 demonstrates a greater thermolability for rabbit muscle G3PDH relative to the enzyme from the hibernator. 
The present study demonstrates that although G3PDH from three sources, rabbit muscle and $C$. Iudivicianus liver and muscle share many characteristics, physical and functional parameters with respect to temperature indicated G3PDH from the hibernator is structurally less rigid but better maintains functional integrity at a range of temperatures, has a greater high temperature stability and is less sensitive to the presence of guanidine hydrochloride relative to the enzyme from rabbit. 
Table 4.1. Purification protocol for G3PDH from C. Iudivicianus liver (Table 4.1a) and C. ludivicianus muscle (Table 4.1b) Assay for activity of fractions was conducted in the direction of G3P oxidation.

\begin{tabular}{lccccc} 
& $\begin{array}{c}\text { Total } \\
\text { Protein } \\
(\mathrm{mg})\end{array}$ & $\begin{array}{c}\text { Total } \\
\text { Activity } \\
(\mathrm{U})\end{array}$ & $\begin{array}{l}\text { Specifi: } \\
\text { \% Yield }\end{array}$ & $\begin{array}{c}\text { Fold } \\
\text { activity } \\
(\mathrm{U} / \mathrm{mg})\end{array}$ & $\begin{array}{l}\text { phre } \\
\end{array}$ \\
\hline \hline Crude extract & 246 & 1266 & 100 & 5.14 & 1 \\
DE-52 & 49.0 & 997 & 79 & 20.4 & 4 \\
HPLC size exclusion & 1.20 & 212 & 17 & 177 & 34 \\
Matrix Red column & 0.50 & 129 & 10 & 257 & 50
\end{tabular}

(1b)

\begin{tabular}{|c|c|c|c|c|c|}
\hline & $\begin{array}{c}\text { Total } \\
\text { Protein } \\
\text { (mg) }\end{array}$ & $\begin{array}{c}\text { Total } \\
\text { Activity } \\
\text { (U) }\end{array}$ & $\%$ Yield & $\begin{array}{l}\text { Specific } \\
\text { activity } \\
\text { (U/ugm) }\end{array}$ & $\begin{array}{l}\text { Fold } \\
\text { pure }\end{array}$ \\
\hline Crude extract & 2110 & 3380 & 100 & 1.60 & 1 \\
\hline DE-52 & 240 & 1824 & 54 & 7.60 & 5 \\
\hline HPLC size exclusion & 4.40 & 804 & 24 & 183 & 114 \\
\hline Metrex Red column & 1.50 & 423 & 13 & 282 & 176 \\
\hline
\end{tabular}


Table 4.2. Maximal activities and activity ratios of muscle G3PDH from rabbit and $\mathrm{C}$. ludivicianus at 22 and $5^{\circ} \mathrm{C}$. Assays were performed at optimal substrate concentrations in imidazole buffer, set to $\mathrm{pH} 7.5$ at $22^{\circ} \mathrm{C}$ and allowed to fluctuate with temperature. Data is presented as means \pm SEM. In all cases, there were no significant differences between hibernating or euthermic tissues. Values in each direction of catalysis are significantly different between tissue groups and species at the $P<0.005$ level of significance. Supersiript a denotes significant differences in ratios at $5^{\circ} \mathrm{C}$ from the corresponding activity ratio at $22^{\circ} \mathrm{C}$. 
Table 4.3. $\mathrm{Km}$ values at two temperatures for the four substrates of purified G3PDH from C. ludivicianus: liver and muscle and rabbit muscle. All assays were conducted at $22^{\circ} \mathrm{C}$ and $5^{\circ} \mathrm{C}$, in $50 \mathrm{mM}$ phosphate buffer at $\mathrm{pH} 7.5$ in the direction of DHAP reduction and $\mathrm{pH} 8.5$ for the determination of $\mathrm{Km}$ values for $\mathrm{NAD}^{+}$. Data is presented as means \pm SEM, $n=3$-j preparations.

Superscript a refers to significant differences from corresponding $22^{\circ} \mathrm{C}$ values at the $p>0.005$.

\begin{tabular}{|c|c|c|c|c|}
\hline Tissue & Temp & $\begin{array}{l}\mathrm{NAD}^{+} \\
(\mathrm{mM})\end{array}$ & $\begin{array}{l}\text { DHAP } \\
(\mathrm{mM})\end{array}$ & $\begin{array}{l}\text { NADH } \\
(\mu \mathrm{m}) \\
\end{array}$ \\
\hline \multicolumn{5}{|l|}{ C. Iudivicianus } \\
\hline \multirow[t]{2}{*}{ liver } & $22^{\circ} \mathrm{C}$ & $0.045 \pm 0.003$ & $0.352 \pm 0.003$ & $1.0 \pm 0.2$ \\
\hline & $5^{\circ} \mathrm{C}$ & $0.090 \pm 0.001 a$ & $\begin{array}{l}0.259 \pm \\
0.004^{a}\end{array}$ & $1.0 \pm 0.1$ \\
\hline \multirow[t]{2}{*}{ muscle } & $22^{\circ} \mathrm{C}$ & $0.143 \pm 0.004$ & $0.279 \pm 0.004$ & $3.0 \pm 0.2$ \\
\hline & $5^{\circ} \mathrm{C}$ & $0.155 \pm 0.005$ & $\begin{array}{l}0.154 \pm \\
0.004^{a} \\
\end{array}$ & $1.0 \pm 0.3$ \\
\hline \multirow[t]{2}{*}{ Rabbit muscle } & $22^{\circ} \mathrm{C}$ & $0.144 \pm 0.0033$ & $0.404 \pm 0.002$ & $5.0 \pm 0.5$ \\
\hline & $5^{\circ} \mathrm{C}$ & $0.259 \pm 0.004 a$ & $\begin{array}{l}0.504 \pm \\
0.009 a\end{array}$ & $4.0 \pm 0.2$ \\
\hline
\end{tabular}


Figure 4.1. SDS-PAGE of purified glycerol-3-prcsphate dehydrogenase from C. Ludivicianus liver (lane 2) and muscle (lane 3). Standards in lane 1 are listed in Materials and Methods. 

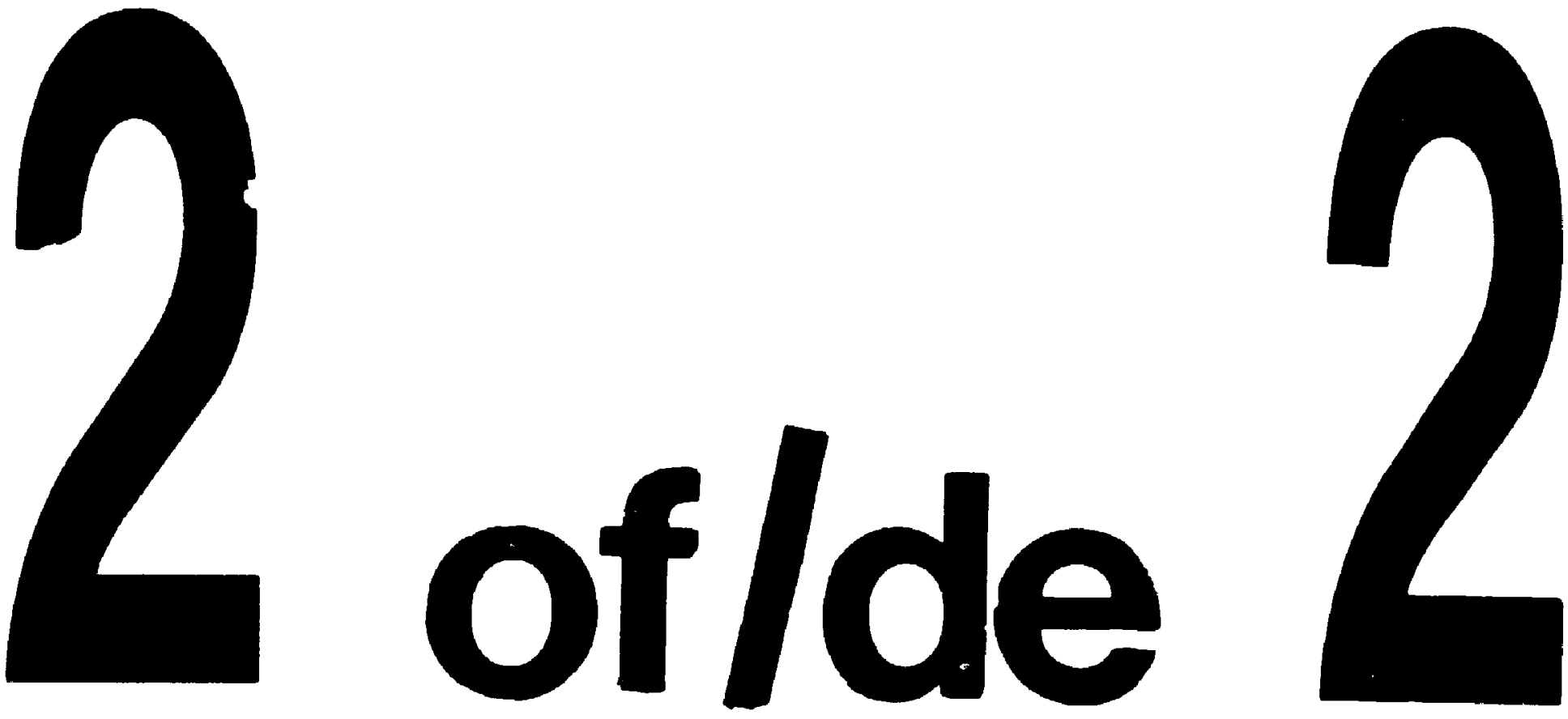

PM-1 3\%ँ"x4" PHOTOGRAPHIC MICROCOPY TARGFT NBS 1010a ANSI/ISO \#2 EOUIVALENT

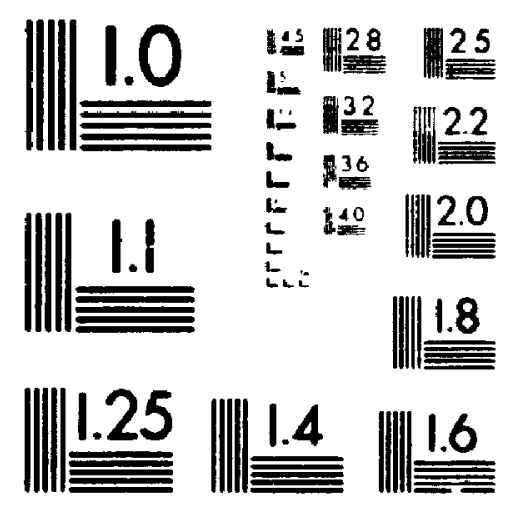

PRECISIONSM RESOLUTION TARGETS 
Figure 4.2. Effect of assay temperature on $\mathrm{Km}$ values for $\mathrm{G} 3 \mathrm{P}$ of purified skeletal muscle G3PDH from rabbit and $C$. ludivicianus. All points are mean \pm SEM (3). 
Figure 4.3. Fluorescence emission intensity at $340 \mathrm{~nm}$ as a function of temperature for $C$. Iudivicianus and rabbit muscle G3PDH. Each point represents a single measurement. Slopes of both lines were $-0.235\left(r^{2}=0.99\right)$ for $C$. Iudivicianus muscle and $-0.169\left(r^{2}=0.98\right.$ ) for rabbit muscle and were sigrificantly different. 
Figure 4.4. Thermolability curves of purified C. ludivicianus and rabbit muscle G3PDH induced by incubation of the enzyme at $37^{\circ} \mathrm{C}$. All points are means \pm SEM and are the mean of 4 preparations. 
Figure 4.5. Unfolding transition curves of G3PD 4 induced by increasing concentrations of guanidine hydrochloride and monitored by $\lambda_{\max }$ displacement. Inset: corresponding loss of activity as a function of increasing guanidine hydrochloride concentration. All activity measurements are the mean of three determinations; error bars represent SEM. Data determined from fluorescence measurements is the product of a single determination. 


\section{Chapter 5}

\section{General discussion}


The variety of mechanisms used by hibernating species to modulate enzyme activity during torpor can be classified as either active or passive forms of regulation. Active regulation involves the aiteration of enzyme activity to increase or supress flux in a páricular metabolic pathway. This can occur by a variety of mechanisms (discussed in chapter 1); in this study, active control in $S$. lateralis was determined in terms of the alteration of enzyme maximal activities. Conversely, enzyme activities can be adapted to environmental effects which presents a form of passive control. In this study, this was determined by a comparison of functional and structural differences between enzymes from hibernating and non-hibernating species with respect to their responses to temperature change. These two mechanisms will be discussed.

\section{Active controi}

The changes in metabolic flux potential presents an active form of metabolic control, which can be determined from maximal enzyme activities in the hibernating and euthermic states. In S. lateralis, glycolytic enzyme activities were generally reduced during hibernation in liver, kidney muscle and WAit, while in heart, their levels increased. However, activities of the enzymes PK and PFK, two important loci of glycolytic control, did not change. Previous studies have demonstrated that these enzymes may be regulated by allosteric effectors such as fructose 2,6-bisphosphate, an effector of PFK, which has previously been shown to increase in muscle and heart of $S$. lateralis during hibernation, but remain constant in liver and kidney (Brooks and Storey 1992). The data presented here suggests that glycolysis is not strongly regulated. 
Decreased glycolytic flux characteristic during hibernation (Tashima et al. 1970) is likely a function of lowered glucose availability brought about by a reduction in glycogen catabolism (Brooks and Storey 1992, de la Roche and Storey, unpublished results).

Enzyme activities associated with NADPH production demonstrated a major trend during hibernation. All activities tested decreased or remained constant during hibernation indicating a decreased metabolic flux potential towards the generation of NADPH. The net result is a limit to all biosynthetic processes. In contrast, enzyme activities associated with protein catabolism demonstrated no uniform trends. Because levels of these enzymes are relatively high, their function is likely governed by substrate availability.

The TCA cycle is strongly regulated by activities of (NAD)IDH and KGDH whose activities either increased or did not change in all tissues except WAT. This indicates an increased TCA cycle flux potentialduring hibernation, likely governed by substrate availability, either via pyruvate dehydrogenase or anapleurotic pathways. Although increases in TCA cycle flux potential may have no relevance to the torpid animal, the arousal process involves an explosive flux of metabolic substrate which may require an increased TCA cycle capacity. In kidney and heart, the flux of glycolytic carbon into the TCA cycle is severely inhibited by the conversion of the active $\underline{a}$ form of PDH to the inactive $\underline{b}$ form by covalent modification.

Quantification of B-hydroxybutyrate ( $\mathrm{BOHB}$ ) in hibernating and euthermic tissues of $S$. lateralis, $C$. ludivicianus, and $R$. ratus demonstrated an increase in levels of BOHB during hibernation purporting a greater reliance on fatty acid 
mobilization. The general mechanisms for this are unclear. Enzyme activities thought to regulate fatty acid metaboiism are COT and CPT both of which incr-ased during hibernation in most tissues. In a variety of metabolic states. CPT is regulated by concentrations of malonyl-CoA, however, the present study suggests that increases in enzyme activity play a prominent role in regulating fatty acid catabolism during hibernation.

The physiological state of $S$. lateralis during bouts of torpor is a function of substrate flux potential through biochemical pathways which in turn are a function of enzyme activities associated with these pathways. This study demonstrates that the change in enzyme activities in hibernating versus euthermic $S$. lateralis plays a prominent role in increasing the metabolic flux potential associated with fatty acid oxidation, and supressing this flux in the pathways of glycolysis, biosynthesis and glycolytic entry into the TCA cycle in various tissues of $S$. lateralis.

\section{Passive control}

Passive control in terms of enzyme adaptation in heterothermic species is a more subtle form of metabolic control during torpor. Elucidation of these adaptations arises from a consideration of structural and functional differences between hibernating species relative to animals that do not hibernate.

Functional parameters of $B$-hydroxybutyrate dehydrogenase (BDH) were determined in extracts from $S$. lateralis, $C$. ludivicianus and rat. Characterisation of this enzyme on the basis of activation energy, maximal activity and $\mathrm{pH}$ behavior demonstrates that the suppression of maximal enzyme activity is solely 
a functicn of the reduction in temperature in the three species. However, $\mathrm{BDH}$ was distinguishing between hibernating and non-hibernating species in terms of $\mathrm{Km}$ values for $\mathrm{B}$-hydroxybutyrate. Whereas, $\mathrm{Km}$ values were maintairied for $\mathrm{BDH}$ from both $S$. lateralis and $C$. Iudivicianus, this kinetic parameter decreased throughout the range of temperatures for the rat enzyme.

Functional and structural adaptations of enzymes in hibernating species were further explored in the muscle enzyme glycerol-3-phosphate dehydrogenase (G3PDH). The muscle enzyme was purified from $C$. ludivicianus, a hibernator and compared to that frc.n rabbits, a non-hibernating control. Characterisation of the purified enzyme involved isoelectric focusing, $\mathrm{pH}$ optima. activation energy and temperature modulation of maximal activity, which were the same in all three species. However, $\mathrm{Km}$ values were again distinctive for the hibernating species, and better maintained at the temperature range of 5 to $40^{\circ} \mathrm{C}$ relative to the changes throughout this range experienced by G3PDH from the non-hibernator. Temperature induced conformational changes determined by enzyme fluorescence measurements indicate a greater degree of conformational change in muscle G3PDH from C. ludivicianus relative to the enzyme from rabbits. Stability was also used as a criterion for elucidating structural differences Detween G3PDH from the two animals. In the presence of both temperature and chemical denaturation, G3PDH from C. ludivicianus was more stable than the rabbit enzyme. This is likely a product of structural integrity, as enzyme fluorescence measurements in the presence of increasing concentrations of guanidine hydrochloride demonstrate a greater degree of unfolding transitions for G3PDH from rabbit. These results imply functional and structural adaptations of this enc̈/me in hibernating species. 
In summary, metabolic adjustments to hibernation in $S$. Iateralis are a function of both an active and a passive regulation. Active regulation involves the alteration of enzyme activities in order to route carbon in such a manner as to ensure the most efficient use of stored metabolic fuel. In addition, passive metabolic control is a result of adaptational differences in hibernator enzymes. for function at a range of temperatures. 


\section{Appendices}


Appendix I. Steady state kinetics.

There are two basic parameters that describe enzyme action; these are Vmax and $\mathrm{Km}$. Vmax is the maximum activity of an enzyme at saturating concentrations of substrate, whereas, $\mathrm{Km}$ describes the concentration which yields $1 / 2$ of Vmax. Vmax is proportional to the total enzyme concentration, and is the product of the rate of catalysis and the concentration of the enzyme defined as follows:

\section{$V \max =k \operatorname{cat}[E]$}

where kcat is the rate of catalysis, or the rate of dissociation of the enzymesubstrate (ES) complex (see below).

The other parameter, $\mathrm{Km}$, is independant of enzyme concentration. A simple single substrate and product enzyme catalysed reaction scheme is as follows:

$$
\begin{aligned}
& \text { k1 k2 } \\
& E+S \leftarrow B S \rightarrow E+P \\
& \text { k-1 }
\end{aligned}
$$

In general, the rate of dissociation is generally more rapid than the conversion to product (ie. $k-1 \gg \mathrm{k} 2$ ) and therefore, $\mathrm{Km}$ is a function of the dissociation of the Michaelis complex:

$$
K m=\underline{k}_{2}+k_{-1}
$$


In some cases. however, intermediate forms of the Michaelis complex along the reaction pathway are present in significant amounts, and will result in smaller dissociation constants than predicted above.

$\mathrm{Km}$ values are aii indicator of changes in the equilibrium dissociation constant when some other parameter (such as temperature) is altered, $\mathrm{Km}$ values were used as an indicator of the functional integrity of an enzyme with decreased temperature. Furthermore, because $\mathrm{Km}$ values are a function of enzyme-substrate dissociation, they are strongly altered by even subtle changes in the active site. As a result, this parameter was used as a sensitive probe of functional behavior and changes in active-site integrity with temperature and compared between enzymes from a hibernating and a non-hibernating species. 


\section{Appendix II. The effect of Alphastat modulation of enzyme activity during hibernation.}

During hibernation, there are two factors which contribute to acidotic modulation of enzyme activity during hibernation. The first is the effect of changes in intracellular $\mathrm{pH}$ experience during hibernation which is a result of apnoic breathing and hypercapnia. The second is the effect of temperature on the pKa of intracellular histidine, the major intracellular buffer. This is known as the alphastat model and involves a basic shift of intracellular pKa arising from the effect of temperature on the histidine residues of protein. This allows for protein function and structure to be conserved with charges in temperature, a result of the shifts in enzyme pKa that mimic that of the cell. As a result, both an acid shift of intracellular $\mathrm{pH}$ and a basic shift of protein pKa result in a modulation of activity for $\mathrm{pH}$ sensitive enzymes. In this study, this was explored by determining energies of activation from Arrhenius plots for glycerol-3-phosphate dehydrogenase which is an indication of maximal enzyme activity changes over temperature. Arrhenius plots were performed in two buffers, tris, one whose pKa shifts strongly with temperature, and phosphate, one whose pKa shifts very little with temperature. These two buffers were specifically chosen to exagerate a situation where changes in pKa with temperature are more and less prominent, respectively, than changes in intracellular pKa. In this experiment, there was no difference in activation energies determined in the two buffers demonstrating that the effect of alphastat regulation on activity during hibernation is not a factor in modulating enzyme activity. 


\section{References}


Arnold, H. and Pete, D. (1970). Binding of aldolase and triosephosphate dehydroger.ase to F-actin and modification of catalytic properties of aldolase. Eur. J. Biochem., $15: 360-366$.

Barman, T.E. (1969). Enzyme Handbook, Vol. 1. Berlin-Heidelberg, SpringerVerlag, pp 51-52.

Borgmann, A.I. and Moon, T.W., (1976). Enzymes of the normothermic and hibernating bat, Myotis lucifugus : temperature as a modulator of pyruvate kinase. J. Comp. Physiol. 107: 185-199.

Bradford, M.M. (1976). A rapid and sensitive method for the quantification of microgram quantities of protein utilizing the principle of protein-dye binding. Anal. Biochem. 72: 248-254.

Brooks, S.P.J. (1992). A simple computer program with statistical tests for the analysis of enzyme kinetics. BioTechniques $13: 906-911$.

Brooks, S.P.J. (1994). The microplate analysis program. Biotechniques, 17(6). $1154-1161$.

Brooks, S.P.J. and Storey, K.B. (1992). Mechanisms of glycolytic control during hibernation in the ground squirrel Spermophilus lateralis. J. Comp. Physiol. B, 162: 23-28.

Crowe, J.H. and Clegg, J.S. eds. (1978). Dry biological systems. Academic Press, New York.

Dark, J. and Ruby, N.F. (1993). Metabolic fuel utilization during hibernation. In 'Life in the Cold', Carey, C., Florant, G., Wunder, B.A. and Horowitz, B, Eds, Westview Press, 167-174.

Dawson, R.M.C., Elliot, W.H., Elliot, D.C., Jones, K.M. Eds. (1979). Data for Biochemical Research. 3rd Ed., Oxford University Press, 418-448.

Eftink, M.R. (1994). The use of fluorescence methods to monitor unfolding transitions in proteins. Biophys. J., 66: 482-501. 
Elnageh , K.M. and Gaitonde, M.K. (1988). Effect of a defficiency of thiamine on brain pyruvate dehydrogenase : enzyme assay by three different methods. J. Neurochem., 51, 1482-1489.

Fevold, H.R. (1986). Body temperature during hibernation. Trends Biochem. Sci. 11,510 .

Fleischer, S., McIntyre, J.O., Churchill, P. Fleer, E. and Maurer, A. (1983). D-B-hydroxybutyrate dehydrogenase: a molecular biology approach to the study of a lipid requiring enzyme. In Structure and function of membrane proteins. Quagliariello, E. and F. Palmieri. Elsevier Science Publishers B.V., The Netherlands. pp. 283-300.

Foe, L.G. and Kemp, R.G. (1982). Properties of phospho and dephospho forms of muscle PFK. J. Biol. Chem., 257, 6368-6372.

Galster, W.A. and Morrison, P.R. (1975). Cyclic changes in carbohydrate concentrations during hibernation in the Arctic ground squirrel. Am. J. Physiol. 218: 1228-1232.

Gotterer, G.S. (1967). Rat liver D-B-hydroxybutyrate dehydrogenase. I. Partial purification and general properties. Biochemistry 6(7): 2139-2146.

Harlow, H. J. and Menkens, G.E. (1975). A comparison of the black-tailed prairie dog, white-tailed prairie dog and Wyoming ground squirrel. Can. J. Zool. 64: 793-796.

Heldmaier, G., Steiger, R. and Ruf, T. (1993). Metabulic suppression during hibernation. In: Life in the Cold, Carey, C., Florant, G., Wunder, B.A. and Horowitz, B, Eds, Westview Press, Boulder, Colorado 544-548.

Helmerhorst, E. and Stokes, G.B. (1980). Microcentrifuge desalting : a rapid quantitative method for desalting small amounts of protein. Anal. Biochem., 104 : 130-135 1-29. 
Krilowicz, B. L. (1985). Ketone body metabolism in a ground squirrel during hibernation and fasting. Am. J. Physiol. 249 (18), R462-R470.

Lahiri, S. Szidon, J.P. and Fishman, A.P. (1970). Potential respiratory and circulatory adjustments to hypoxia in the African lungfish. Fed. Proc. 29: $1141-1148$.

Lehninger, Albert A. [1975]. Biochemistry, 2nd Ed. Worth Publishers Inc., New York, 1975.

Lyman, C.P. and Chatfield, P.O. (1955). Physiology of hibernation in mammals. Physiol. Rev. 55: 403-425.

Lyman, C.J., Willis, J.S., Malan, A., Wang, L.C.H. (eds.) (1982). Hibernation and torpor in mammals and birds. Acade:nic Press, New York.

Malan, A., Wilson, T.L. and Reeves, R.B. (1973). Pulmonary respiration and acid base state in hibernation and respiratory acidosis in nibernating marmots and hamsters. Respir. Physiol. 17 : 45-61.

Malan, A. (1980). Enzyme regulation, metabolic rate, and acid-base state in hibernation. In: Animals and Environmental Fitness, Gilles, R. (ed), Pergammon, London, pp 487-501.

Malan, A., Rodeau, J.L. and Daull, F. (1985). Intracellular pH in hibernation and respiratory acidosis in the european hamster. J. Comp. Physiol. 156: 251-258.

Malan, A. (1993). "What is a bout of hibernation?" In: Carey, C., Florant, G.L., Wunder, B.A. and Horwitz, B., eds., Life in the cold : ecological, physiological and molecular mechanisms. pp 241-252, Westview Press, Boulder, Col.

Michener, G.R. and Koeppl, J.K. (1985). Spermophilus richardsonii, Mammalian Species. 243: 1-8. 
Nedergaard, J. and Canon, B. (1984). Preferential utilization of brown adipose tissue lipids during arousal from hibernation in hamsters. Am. J. Physiol. 247: R506-R512.

Nedergaard, J. and Canon, B. (1990). Mammalian hibernation. Phil. Trans. R. Soc. Lond. B 326, 669-686.

Nestler, J.R. (1992). Tissue specific metabolism during normothermy and daily torpor in deer mice (Peromyscus maniculatus). J. Exp. Zool. 261 406-413.

Newsholme. E.A. and Crabtree, B. (1986). Maximum catalytic activity of some key enzymes in provision of physiologically useful information about metabolic fluxes. J. Exp. Zool. 293, 159-167.

Robinson, A.M. and Williamson, D.H. (1980). Physiological roles of ketone bodies as substrates and signals in mammalian tissues. Physiol. Rev. 60: 143-187.

Sacchetta, P., Aceto, A. Bucciarelli, T., Dragani, B., Santarone, S., Allocati, N. and Di-ilio, C. (1993). Multiphasic denaturation of glutathione transferase B1-1 by guanidinium chloride. Eur. J. Biochem. 215, 741-745.

Seymour, R.S. (1973). Energy metabolism of dormant spadefoot toads (Scaphiopus). Copeia 1973: 435-445.

Snapp, B.D. and Heller, H.C. (1981). Suppression of metabolism during hibernation in ground squirrels (Citellus lateralis). Physiol. Zool. 54 : 297 307.

Srere, P.A. and Ovadi, J. (1990). Enzyme-enzyme interactions and their metabolic role. FEBS, 268(2), 360-364.

Srivastava, D.K. and Bernhard, S.A. (1986). Metabolite trasfer via enzymeenzyme complexes. Science 234, 1081-1086.

Storey, K.B. (1987a). Investigations of the mechanisms of glycolytic control during hibernation. Can. J. Zool. 65: 3079-3083. 
Storey, K.B. (1987b). Regulation of metabolism by enzyme phosphorylation during mammalian hibernation. J. Biol. Chem 262, 1670-1673

Storey, K.B. and Storey, J.M. (1992). Natural freeze tolerance in ectothermic vertebrates. Annu. Rev. Physiol. 54: 619-637.

Storey. K.B. (1993). Mechanisms of metabolic arrest in mollusks. In Surviving Hypoxia. Hochachka, P.W., P.L. Lutz, T.J. Sick, M. Rosenthal adn G. van den Thillart eds. CRC Press, Boca Raton, pp. 253-269.

Tashima, L.S., Adelstein, S.J. and Lyman, C.P., (1970). Radioglucose utilization by active, hibernating and arousing ground squirrels. Am. J. Physiol. 218 , 303-309.

Tileston, J.V. and Leichleitner, R.R. (1966). Some comparisons of the Black-tailed and White-tailed prairie dogs in north-central Colorado. Am. Mid. Nat. 75(2), 292-316.

Twente, J.W. and Twente, J.A. (1965). Effects of core temperature upon the duration of hibernation in Citellus lateralis. J. Mammal. 48 : 381-386.

Wang, L.C.H. (1978). Energetics and field aspects of mammalian torpor: the Richardson's ground squirrel. In: Wang, L.C.H., Hudson, J.W. (eds.) Strategies in the cold: natural torpidity and thermogenesis. Academic Press, London, pp 109-145.

Wang, L.C.H. (1979). Tıme patterns and metabolic rates of natural torpor in the Richardson's ground squirrel. Can. J. Zool. 57, 149-155.

Wang, L.C.H. (1987). Mammalian hibernation. In: Morris, G.J., Grout, B. (eds.), The effects of temperature on biological systems, Arnold, London, pp 349386.

Wang, L.C.H. (1989). Ecological. physiological and biochemical aspects of torpor in mammals and birds. In Wang, L.C.H. (ed.), Advances in comparative and environmental physiology, vol. 4, Springer-Verlag, Berlin, pp 362-401. 
Vesterberg, O. (1971). Isoelectric Fccusing In: Colowick, S.P.; Kaplan, N.O. (eds) Methods in Enzymology. New York, Academic Press, pp 389-412.

White, Harold B. (1971). The molecular weights of glycerol-3-phosphate dehydrogenases from chicken, rabbit and honey bee. Arch. Biochem. Biophys. 147, 123-128.

Yacoe, M.E. (1983). Adjustments of metabolic pathways in the pectoralis muscle of the bat Eptesicus fuscus, related to carbohydrate sparing during hibernation. Physiol Zool. 56, 648-658. 

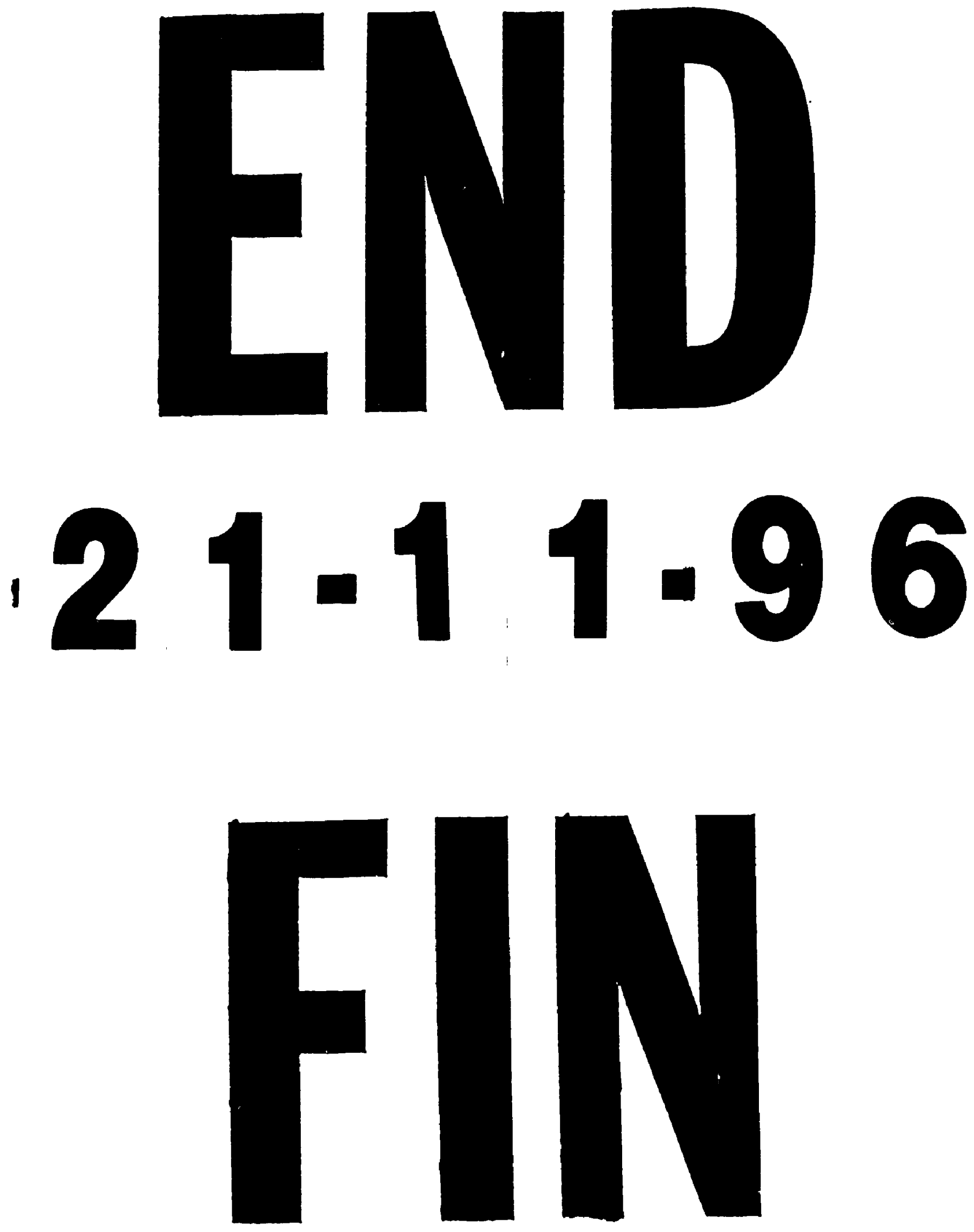